\title{
EL ESTABLECIMIENTO DE LOS PRINCIPIOS DE JUSTICIA ELECTORAL. ANÁLISIS COMPARADO EN LAS LEGISLACIONES LOCALES.
}

\section{ESTABLISHMENT OF THE ELECTORAL JUSTICE PRINCIPLES. COMPARED ANALYSIS IN LOCAL LEGISLATIONS.}

Francisco Jaime Hidalgo González Licenciado en Derecho por la Universidad La Salle Pachuca, Profesor Investigador del Centro de Estudios Constitucionales y Derechos Humanos del

Estado de Hidalgo.

franciscojaimehidalgo1@hotmail.com

Emir López Badillo Doctor en Derecho por la Universidad Carlos III de Madrid, Académico de la Escuela de Derecho de la Universidad La Salle Pachuca y de El Colegio del Estado de Hidalgo. emir64@hotmail.com

\section{Resumen}

Este ensayo tiene la finalidad de plasmar los conceptos y criterios más significativos en lo referente a la forma de gobierno democrática y su vinculación con la Justicia y el Derecho, conformándose una serie de criterios que son complementarios entre ellos.

Comenzaremos estableciendo los criterios más significativos en torno a la idea de justicia con la finalidad de ir entrelazándolos con los conceptos de poder, Derecho, Estado Constitucional de Derecho, gobierno democrático y finalmente con lo concerniente a la justicia electoral, derecho constitucional y derecho constitucional electoral; con ello, sentaremos las bases para el desarrollo de un estudio legislativo electoral con la finalidad de identificar en las legislaciones locales electorales vigentes en todas las entidades federativas que principios de justicia electoral establecen, sustentando toda la actividad administrativa y jurisdiccional electoral en el país.

Palabras clave: Justicia, Derecho, Política, Estado, Gobierno democrático, Justicia electoral, Derecho Constitucional electoral.

\section{Abstract}


This essay is intended to express the most significant concepts and criteria regarding to the democratic form of government and its linkage to Justice and Law, setting a number of complementary criteria.

We will start by setting the most significant criteria around the idea of justice in order to intertwine them with the concepts of power, law, constitutional state of law, democratic government and finally with regard to electoral justice, constitutional law and electoral constitutional law, we will lay the foundation for the development of an electoral legislative study in order to identify local election laws in all the states that established principles of electoral justice, supporting all the administrative and judicial electoral activities in the country.

Key words: Justice, Law, Politics, State, Democratic government, Electoral justice, Electoral Constitutional Law

\section{Justicia}

El concepto que abrirá la puerta a este estudio es el de Justicia, así, sobre el particular existen un gran número de referencias para tratar de explicar este término, desde Platón y Aristóteles hasta Kelsen y Bobbio.

Cada uno de los autores, estudiosos y doctrinarios de todas las Ciencias Sociales han tratado de definir este concepto, ampliando cada vez más su concepción.

A continuación, trataremos de hacer uso de estas aportaciones que a lo largo de la historia han aparecido para fijar un criterio base que será el hilo conductor de nuestro análisis.

Uno de los primeros referentes para estudiar a la Justicia lo tenemos en Aristóteles, él advierte una conexión entre legalidad y justicia, pero esto sólo a nivel conceptual, ya que sabemos que la noción de legalidad no conlleva la noción de justicia, pero el supuesto no aplica al contrario, no se puede conceptualizar a la justicia sin la legalidad.

Así, a nivel conceptual nadie podría negar lo primero, pero a nivel empírico queda claro que se necesitan establecer criterios racionales que permitan la valoración pertinente de los criterios de aplicación de la norma o ley, ya que la creación misma de una norma a través de los procedimientos formales establecidos no presupone que ésta sea justa.

De esta manera Aristóteles visualizó la distinción entre justicia natural o universal y la justicia legal o particular, siendo la natural aquella que cuenta con el mismo criterio de obligatoriedad para su cumplimiento y que queda fuera su formulación del criterio humano y, la segunda de ellas, será aquella que ha sido definida y creada por cada pueblo y mantiene una relación consigo mismo. 
Haciendo referencia a la conceptualización anterior Aristóteles escribió en el Libro I de la Política

"pero la palabra está para hacer patente lo provechoso y lo nocivo, lo mismo que lo justo y lo injusto; y lo propio del hombre con respecto a los demás animales es que él sólo tiene la percepción de lo bueno y de lo malo, de lo justo de lo injusto de otras cualidades semejantes; y la participación común en estas percepciones es lo que constituye la familia y la ciudad. ... parece que la justicia es igualdad, y lo es, pero no para todos, sino para los iguales. Y la desigualdad parece ser justa, y lo es en efecto, pero no para todos, sino para los desiguales. Pero se prescinde de "para quienes», y se juzga mal. La causa de ello es que el juicio es acerca de sí mismo y, por lo general, la mayoría son malos jueces acerca de las cosas propias (...) Pero la igualdad es de dos clases: la igualdad numérica e igualdad según el mérito. Entiendo por numérica lo que es idéntico o igual en cantidad o tamaño, y según el mérito lo que es igual en proporción. Por ejemplo, numéricamente, tres excede a dos y dos a uno en igual cantidad, y proporcionalmente cuatro sobre dos es igual que dos sobre uno, pues igual fracción es dos de cuatro y dos de uno, en ambos casos es la mitad. Y aunque todos están de acuerdo en que lo absolutamente justo es la igualdad según el mérito, disienten, como se dijo antes, los unos porque, si son iguales en un aspecto, creen ser completamente iguales, y los otros porque, si son desiguales en algún aspecto reclaman para sí la desigualdad en todo". (Aristóteles; Libro I de la Política; p.2)

Con estas aseveraciones Aristóteles plantea el eje rector que determinará el concepto de lo justo, así, la justicia legal o particular, ya definida con anterioridad, se entenderá desde el principio de igualdad pero entendiéndolo como al principio de equidad, dar a cada quien lo que le corresponda, según una serie de criterios.

Este principio sólo se aplicará de manera eficiente en la justicia legal o particular, lo que no conlleva que a nivel empírico pueda equipararse la legalidad con la justicia, entendida esta como equidad, aparejado, en el mismo sentido, principio de isonomía.

De esta manera se establecen criterios de distinción en la persecución de la justicia (Bobbio, 1994), lo que da pie a una nueva clasificación, así, estos criterios serán, entre los individuos, dar un bien por un bien y un mal por un mal, dando pie a la justicia conmutativa y, entre los individuos y el Estado, en donde este último distribuirá honores y gravámenes o derechos y obligaciones instituyéndose la justicia distributiva en función del mérito, el trabajo y la necesidad.

Otro posicionamiento en torno a la idea de Justicia lo encontramos en el jurista Hans Kelsen (2002), a la Justicia debe de entenderse como una característica posible, aunque no necesaria, del orden social, a su vez, Kelsen la considera como una virtud del individuo, un valor de orden ya que equipara lo justo con el accionar del hombre cuando este actuar coincide con el orden social. Pero este orden social debe de entenderse según Kelsen, siguiendo el pensamiento de Platón, como la felicidad, la dicha del hombre en comunidad, en sociedad, de esta 
manera, aspiramos a la justicia en el sentido que aspiramos a la felicidad de todos los seres humanos.

Pero, en este sentido, Kelsen argumenta que el concepto de felicidad es subjetivo y se determina en función de la satisfacción de necesidades, siguiendo la primera etapa de la escuela utilitarista de Bentham y, secundada y perfeccionada por John Stuart Mill.

La satisfacción de necesidades conlleva a la felicidad, pero, qué necesidades, no sólo las básicas e inmediatas sino las morales e intelectuales $y$, citando a John Stuart Mill diremos en lo concerniente a la satisfacción de necesidades escribió que "más vale ser un hombre insatisfecho que un cerdo satisfecho, más vale ser Sócrates insatisfecho que un necio o loco satisfecho". Para Kelsen la justicia engloba una serie de valores ético - normativos los cuales serán la razón, la libertad, la paz y la tolerancia.

Siguiendo con nuestro análisis, tomaremos como referencia a la libertad como eje rector del concepto de Justicia y, por ende, de lo justo.

De acuerdo con Jonh Rawls (2002) los principios de justicia y, en este sentido, de lo justo, son aquellos que elegirán personas libres y puramente racionales, que solamente se preocupan por su propio interés, si estuvieran en una posición original de igualdad, de aquí se desprende el "Primer Principio", en el cual todos los individuos tienen igual derecho de participar en un sistema de libertades básicas para todos, es decir, igualdad de participación en un sistema universal de libertades.

Así, se tendrá presente que el concepto de Justicia hace referencia a un conjunto de principios y valores éticos normativos a los cuales se procurará llegar a través tanto de la aplicación del Derecho, es una idea de justicia formal, así como del ejercicio del poder político.

Los conceptos de Justicia antes citados hacen referencia una serie de valores descriptivos del término emulando a la Justicia como igualdad, equidad, felicidad, orden social, paz, razón, tolerancia y libertad.

Estas conceptualizaciones del término Justicia ha traído consigo una serie de argumentaciones encontradas ya que para algunos la Justicia debe de ser entendida como un valor en sí que conlleva lo Justo; en medio del posicionamiento se encuentran aquellos que determinan a la Justicia como un principio general que engloba una serie de valores secundarios como la igualdad, libertad, orden, paz social etc. y, en el extremo conceptual, se encuentran los que consideran que la Justicia no se debe de tratar ni equiparar a una "cosa" prescindiendo del término para utilizar sólo un concepto normativo de lo justo definiendo a éste último como igualdad, libertad u orden. 
De esta manera, siguiendo el pensamiento de Norberto Bobbio (1994), el orden jurídico que deriva del derecho objetivo, es decir la norma o texto en sí, derecho positivo, ya sea en el ámbito de ordenamiento o regulación Constitucional, Civil, Penal, Electoral etc. se compondrá por un sistema de reglas vinculantes u obligatorias que regulan las relaciones de los individuos pertenecientes a una comunidad. Pero el cumplimiento de estas premisas son sólo condiciones necesarias, mas no suficientes, para que la norma en sí cumpla su función, además, procurará este cuerpo normativo que, aunado al proceso mismo de su creación y demostración, tenga como condición sustancial la protección de principios ético-normativos, para así llegar a lo Justo.

En este tenor de ideas, haremos referencia a dos áreas del Derecho, que a su vez determinarán posicionamientos ideológicos entorno a la idea de la Justicia, nos referimos al Constitucionalismo y al Neoconstitucionalismo.

Así, a grosso modo y tomando como referencia a Paolo Comanducci (2002) se entenderá al Constitucionalismo en sentido amplio como "la ideología que requiere la creación de una -cualquiera- constitución, a fin de limitar el poder y prevenir el despotismo... el Constitucionalismo en sentido restringido es la ideología que requiere la creación de un tipo específico de constitución a fin de limitar el poder, y de prevenir el despotismo", (Comanducci, 2002, p. 91) de esta manera el Constitucionalismo requiere una constitución para legitimar y limitar el ejercicio de poder político del Estado y, con ello, garantizar los derechos y libertades individuales.

De igual manera, el Maestro Héctor Fix Zamudio (2009), en su obra Derecho Constitucional Mexicano y Comparado, desarrolla una serie de premisas en torno al concepto de Derecho Constitucional y, por ende, al de justicia, tomándola desde un punto de vista formal.

Así, el Maestro Fix Zamudio, haciendo referencia al jurista y politólogo Prélot, afirma que al Derecho Constitucional, entendiéndolo como Derecho Positivo, se entenderá, en la acepción más ortodoxa de la interpretación de la ciencia del derecho, como una "técnica de autoridad", entendida como ciencia de las reglas jurídicas según las cuales se establece, ejerce y transmite el poder político.

Así, desde el origen del concepto mismo de Derecho Positivo y, en específico del Derecho Constitucional, se percibe a la Constitución como un instrumento de control del ejercicio de poder político, influyendo, de igual manera, en el concepto mismo de Justicia y de la creación y aplicación del Derecho para procurar alcanzar el valor deseado de lo Justo.

Retomando los conceptos de Paolo Comanducci (2002) en lo concerniente al Neoconstitucionalismo o el Nuevo Constitucionalismo, lo entiende como aquel que “... tiende a distinguirse parcialmente de la ideología constitucionalista ya que pone en segundo plano el objetivo de la limitación del poder estatal -que era por el contrario absolutamente central en el constitucionalismos de los siglos XVIII y XIX- 
, mientras pone en primer plano el objetivo de garantizar los derechos fundamentales". (Comanducci, 2002, p. 93)

Como nos podemos dar cuenta, existe diferencia con respecto a los objetivos o finalidades que cada una de estas ideologías del Derecho persigue y, por lo tanto una diferencia en las metodologías tanto de su interpretación así como de su misma aplicación, lo que repercute en diferentes acepciones de los términos Justicia y Justo.

En este sentido, el Estado Moderno o Constitucional de Derecho tendrá como elementos esenciales la desmonopolización tanto del poder ideológico como del poder económico y, en el mismo tenor, la institucionalización formal del poder político, el cual estará sujeto, tanto para su creación como para su ejercicio, en el marco legal fundamental y, de igual forma, un elemento sustancial necesario para su existencia, la tutela de los bienes o derechos individuales o constitucionales. El reconocimiento expreso de derechos fundamentales en derechos constitucionales, como lo establece el artículo primero de nuestra Constitución Política, la búsqueda del ejercicio pleno de estos derechos institucionalizados en el régimen político y que son goce de todo individuo, el sometimiento de todos los individuos a la Ley además del establecimiento de mecanismos operativos de creación, ejercicio y control del ejercicio del poder político, condicionarán de una manera más favorable el acceso a una vida social plena tendiente a la seguridad y certeza jurídica, en este sentido al ideal de la Justicia y de lo Justo.

\section{Estado mínimo y estado constitucional de derecho}

El Estado Moderno o también llamado Estado Constitucional de Derecho afirma que el ejercicio del poder político debe de estar regulado y limitado por la razón hecha Ley y, a su vez, su uso deberá garantizar el efectivo ejercicio de los derechos del individuo frente a este mismo ejercicio de poder.

Así, se desarrolla el concepto minimalista del Estado o Estado mínimo, lo que no quiere decir débil; el Estado mínimo o Estado Liberal se entenderá de igual forma desde la desmonopolización del poder económico y del poder ideológico al cual sólo le quedará el monopolio exclusivo de la violencia física legítima con el sólo objetivo de garantizar un orden mínimo y, en este sentido, el reconocimiento y garantía del ejercicio pleno de libertades y derechos individuales, así, se consolida, con estas características, el Estado Moderno o Constitucional de Derecho.

De esta manera, resulta patente su posicionamiento fundamental en el individuo y en las libertades constitucionalmente garantizadas a todas las personas por medio del ejercicio de los derechos individuales, y como contrapartida, el establecimiento de un gobierno limitado y representativo que mantenga un mínimo orden.

Así, el Estado contará con un aparato de administración de recursos, que en términos amplios conocemos como gobierno; con la finalidad de trazar las bases del concepto tomaremos como primera referencia a Aristóteles; él en su libro de la 
Política estableció un argumento en torno a este concepto, así, comienza el desarrollo de su tema limitando su marco conceptual y, escribió que la manera en que abordará los diferentes temas que desarrolla será desde el punto de vista del devenir natural de las cosas.

Aristóteles como pensador y filósofo tratar de encontrar, mediante procesos racionales, la "verdad de las cosas"; así, la filosofía como actividad hará referencia a la "acción de no hacer" entendida esta como Ocio. En esta actividad de no hacer, el hombre se desconecta del mundo, deja "de hacer" y se desliga de la realidad, del trabajo que lo vincula con el mundo físico. Esa actividad de no hacer lo lleva a conectarse con su interior, admirándose y sorprendiéndose de lo que en ella encuentra, acrecentando su deseo de admiración y duda por lo que en ese interior encuentra; introspección, admiración y duda son los incentivos que llevan al hombre a preguntarse sobre la esencia y fines de las cosas como por la misma esencia y finalidad suya. Así, Aristóteles ejercía la "actividad de no hacer" y con ello, trataba de encontrar los fines de todas las cosas, la verdad de ellas y por ende, el Bien Común y desarrollo del individuo.

En este sentido se basa el concepto clásico de política, como una actividad propia del ser humano que lo vincula con su comunidad, la polis, y la búsqueda del Bien Común.

Aristóteles determinó que, de manera natural, la comunidad está antes que el individuo, por ello, es por naturaleza que nosotros nos asociemos, somos, para él, unos Toon Zoon Politikon, así, señala que la necesidad, en orden a la generación, ha hecho aparearse los unos con los otros, buscando, de igual forma, con esa unión, seguridad, por ello, por esa razón sustancial y natural, hay quienes mandan y quienes obedecen, estableciéndose los primeros criterios de desigualdad y de subordinación basándolas en la división del trabajo con miras a mantener un bienestar social antes que el individual.

Así, sostuvo que

“... Quién por su inteligencia es capaz de previsión, es por naturaleza gobernante y por naturaleza señor, al paso que quien es capaz con su cuerpo de ejecutar aquellas providencias, es súbdito y esclavo por naturaleza, por lo cual el amo y el esclavo tienen el mismo interés." (Aristóteles; Libro I de la Política; p.1)

De esta forma, la subordinación y el ejercicio de poder, se entenderá como aquella probabilidad de que un actor social esté en posibilidad de imponer su voluntad, se da de manera natural. Con este marco conceptual Aristóteles visualiza y describe tres formas de poder o dominio, las cuales están fundamentadas en preceptos éticos-normativos; clasifica dentro de su tipología de poder a la forma paternal, despótica y la política.

El ejercicio de poder paternal es la primera forma de ejercicio de poder ya que, de manera natural, el padre ejerce poder sobre el hijo, buscando siempre el 
perfeccionamiento o bien del hijo; sobre el poder despótico él argumentó que no hay ejercicio de poder más injusto que el que se ejerce con armas y sin reconocimiento o justificación del sentido de justicia y, por ende, de la ley, así, el hombre dotado por la naturaleza de armas las debe de usar de manera justa, es decir, buscando la virtud y la sabiduría; por último, Aristóteles argumenta al poder político el cual se entiende desde la relación gobernante-gobernado; en esta relación el gobernante ejerce poder o dominio sobre el gobernado, buscando siempre el beneficio de la comunidad o el Bien Común y, a su vez, el desarrollo del individuo.

El principio de legitimidad que faculta al gobernante a ejercer poder o dominio sobre el gobernado, argumenta la teoría política clásica será el contrato o consenso; en un sentido axiológico, esta relación tiene una connotación positiva o deseable ya que el actor que ejerce poder o dominio no se beneficia de la relación, de esta manera existe un reconocimiento natural entre la comunidad y el individuo, entre el todo y las partes, entre la Polis y el Ciudadano.

Como consecuencia, la actividad de la política, en el sentido más clásico del concepto, hace referencia a la actividad que se basa en que el ejercicio de poder tiene como fin la consolidación de objetivos colectivos debiendo buscar siempre el bienestar común.

\section{Gobierno y gobierno democrático}

La tipología de poder de Aristóteles da pie al concepto de gobierno, desde la filosofía política, entendiendo a este, desde un punto de vista axiológico, como la organización encargada de ejercer poder con la finalidad de llegar a la consecución de intereses colectivos o al bien común.

Aristóteles plantea, en el Libro II de la Política, la cuestión de cuál será la forma en que tanto la distribución como el ejercicio de poder son las más deseables, por ello, analiza a las Constituciones, es decir, los cimientos ético normativos fundamentales que dan pie al ejercicio de poder político. Aristóteles argumenta tres formas de gobierno puras y sus respectivas contrapartes viciadas. Así, la tipología clásica de las formas de gobierno propuesta por Aristóteles fue la siguiente: Monarquía, Aristocracia y Politeia como formas puras y, como formas viciadas al Despotismo, Oligarquía y a la Democracia.

Debemos de contextualizar a nuestro tiempo la tipología de las formas de gobierno de Aristóteles, por ello, como Politeia, en la actualidad, entenderemos a la Democracia y como Democracia, en la tipología de Aristóteles a la Demagogia.

Desde la perspectiva de la Ciencia Política se han dado una gran variedad de definiciones acerca del gobierno, así, definiendo a la Ciencia Política (Bobbio, 2005) como aquella ciencia encargada de estudiar, en la medida de lo posible, el análisis del fenómeno político, entendiendo a lo político desde a) las condiciones para ser más virtuosos y mejores ciudadanos; b) el monopolio del uso de la 
violencia física legítima; c) la autoritaria distribución de valores para una sociedad y d) las formas de organización y ejercicio del poder, entenderemos al Gobierno, siguiendo a Robert A. Dahl (1971) como aquellas "organizaciones que poseen poder de monopolio suficiente para imponer coactivamente una ordenada solución de conflictos con otras organizaciones de la misma zona." (Dahl, 1971, p.15)

Así, los gobiernos desarrollan funciones especializadas que los diferencian de las demás organizaciones sociales; los diferentes roles que el gobierno desarrolla, siguiendo la teoría republicana o de división de funciones serán la función legislativa, la función ejecutiva y la judicial.

Partiendo del concepto de gobierno dado por Dahl, entenderemos, de igual forma que, esta organización tiene como elemento fundamental, más no el único, la posibilidad de ejercicio de poder político para solucionar de manera ordenada los conflictos dados entre otras organizaciones dando pie al análisis de quien ejerce ese poder político, remitiéndonos al análisis de las formas de gobierno.

Tradicionalmente, se han utilizado tres metodologías para el análisis de las formas de gobierno (Bobbio 2005), la primera de ellas es la metodología descriptiva, la segunda es el análisis prescriptivo o metodología axiológica y la tercera es la metodología histórica.

Así, en los Estados Constitucionales de Derecho o Estados Modernos resulta idealmente deseable que su forma de gobierno sea la democrática ya que como lo señala Michelangelo Bovero (2002) haciendo referencia a la interpretación de Bobbio sobre las relaciones internacionales entre Estados Nación en un mundo cada vez más, por un lado globalizado y, a su vez, sustancialmente desigual en la tutela de derechos constitucionales... "entendía por democratización del sistema internacional la creación de un Tertium super partes, o sea, de un conjunto de instituciones políticas universales dotadas de poderes eficaces y fundadas en el consenso democrático. Resumía finalmente su pensamiento: «El sistema ideal de una paz estable puede expresarse con esta fórmula sintética: un orden universal democrático de estados democráticos». De esta forma concluía: «No necesito agregar que, como todas las fórmulas ideales, también ésta no pertenece al mundo del ser sino al del deber ser»." (Bovero, 2002, p.51)

Con ello, desde el punto de vista descriptivo, Bobbio (Bovero, 2002) argumenta a las formas de gobierno se les entenderá en función de quien ejerce el poder político, así, en la Monarquía el poder político es ejercido por uno, en la Aristocracia por algunos y en la Democracia por muchos, independientemente de quién se beneficia del ejercicio de poder político mismo, en este sentido la forma de gobierno democrática será aquella en donde el poder político es ejercido por muchos.

Desde el punto de vista prescriptivo o axiológico se les otorga un valor, primero al ejercicio de poder y, en una de sus consecuencias, a las formas de gobierno, así, estas se califican de deseables o no deseables, de positivas o negativas. 
La tipología de las formas de gobierno en un uso axiológico no sólo implica un juicio de valor absoluto sobre la conveniencia o inconveniencia de cada una de las formas sino de igual manera a lo bondadosa o no que resulte cada una de ellas en comparación a otras.

El juicio axiológico referente a la forma de gobierno democrática ha cambiado durante toda su existencia, en la actualidad, la percepción en torno a ella es que es positiva o deseable en comparación con otras formas.

La metodología histórica de las formas de gobierno es utilizada para marcar puntos de referencia tratando de encontrar "leyes constantes" que regulan el nacimiento y decadencia de las diferentes formas de gobierno, marcando con ello una especie de ciclos que son determinados por fenómenos sociales y políticos tangibles. La norma principal en la que debe inspirarse el estudio de las formas de poder desde esta metodología consiste en acumular el mayor número posible de datos históricos con la finalidad de encontrar datos conductores o constantes para finalmente compararlos.

La forma de gobierno democrática desde la perspectiva histórica se entiende como una derivación de otras formas de gobierno, fundamentando estos cambios en eventos históricos cruciales. Para fundamentar este criterio Bobbio (Bovero, 2002) utiliza un texto de Montesquieu citando:

"La continuidad de la cultura mundial ha llevado al género humano, después del despotismo oriental, y después de que generó aquella república que había dominado el mundo, a esta posición intermedia entre las dos anteriores" que es "el sistema de representación" propio "de todos los estados europeos modernos." (Bovero, 2002, p.54)

De igual forma, las formas de gobierno se pueden estudiar partiendo de dos criterios, el formal o legal y el sustancial o esencial. Así la forma de gobierno democrática representativa vista desde lo formal, se entiende como lo argumentaba Joseph Schumpeter (1961) como la competencia libre por el voto libre es un arreglo institucional, una instrumentación de mecanismos y reglas formales aceptadas y reconocidas por los actores sociales y políticos con la finalidad de conseguir una institucionalización tanto en el acceso como en el ejercicio del poder político.

Desde lo formal, la democracia moderna representativa es un conjunto de reglas fundamentales, claras y precisas que tienen como finalidad consolidar la voluntad de la mayoría, a través de mecanismos de participación política definidos por las mismas reglas.

Existe, por lo tanto, la idea en este concepto de democracia representativa la existencia de mecanismos institucionales para llegar y ejercer poder político. Uno de esos mecanismos formales son las elecciones, configurándose en un sistema electoral entendido a este como el conjunto de medios a través de los cuales la 
voluntad de los ciudadanos se transforma en órganos de gobierno o de representación política, de esta manera, siguiendo a Adam Przeworski (1998) "hay dos formas en que las elecciones pueden hacer que los gobiernos trabajen en la forma que mejor beneficie a la gente. De acuerdo con una perspectiva -el mandato-, las elecciones sirven para la selección de buenas políticas, o políticos que tengan buenas políticas...Así, las elecciones emulan una asamblea directa y la plataforma ganadora se convierte en el "mandato" con el que el gobierno procede. (Przeworski, 1988, p. 354)

Con ello, se afirma que la conexión entre la democracia y la representación se basa en que en democracia los gobiernos son representativos porque son electos.

El punto que se ha puesto a discusión en torno a la democracia representativa o moderna, en palabras de Przeworski (1998) es el siguiente:

La democracia es una forma de norma. Aún en la democracia directa, las decisiones de una mayoría son obligantes para todos, incluyendo a la minoría, que encuentra que estas decisiones son contrarias a sus opiniones o intereses. En una democracia representativa - nuestra forma de gobierno - estas decisiones son tomadas por representantes electos e implementadas por funcionarios designados en quienes los representantes delegan algunas de las tareas de gobierno. Los representantes deciden lo que los ciudadanos tanto deben hacer como lo que no pueden hacer y los coaccionan para que acaten esas decisiones. Deciden cuánto tiempo los niños deben ir a la escuela, cuánto deben pagar los contribuyentes por concepto de impuestos, con qué países se debe entrar en guerra, qué acuerdos deben suscribir las partes privadas, así como qué pueden conocer los ciudadanos acerca de las acciones del gobierno. Y ellos imponen el cumplimiento de estas normas, aún contra la voluntad de los individuos concernidos. En este sentido, ellos "mandan".

La cuestión de la representación radica en saber por qué los gobernantes, equipados con tales poderes, habrían de actuar en beneficio del interés de otros, de los ciudadanos, o al menos de cierta mayoría de ellos. Esto es lo que queremos significar con "representación": actuar de acuerdo con los mejores intereses del público (Pitkin, 1967).

Con estos conceptos, de acuerdo con sus objetivos, desde el punto de vista formal, los sistemas electorales en perspectiva de Leonardo Valdés se componen de reglas y procedimientos destinados a regular los siguientes aspectos y etapas de los procesos de votación: ¿quiénes pueden votar, quiénes pueden ser votados, de cuántos votos dispone cada elector, cómo pueden y deben desarrollarse las campañas de propaganda y difusión, cuántos representantes se eligen en cada demarcación electoral, cómo se determinan y delimitan los distritos y secciones electorales, quiénes y cómo deben encargarse de organizar los comicios?

De igual forma pretende establecer cómo deben emitirse y contarse los sufragios, cuántas vueltas electorales pueden y/o deben realizarse para determinar al 
triunfador, quién gana la elección y, cómo se resuelven los conflictos que puedan presentarse, entre otros.

\section{Gobierno democrático y el derecho electoral}

En este contexto formal y en un sentido amplio, al Derecho como ciencia se entenderá como un cuerpo normativo que tiene carácter vinculatorio y obligatorio el cual tiene como finalidad regular las conductas externas del individuo en una sociedad, es decir, la norma en sí, pero encuadrándolo a la regulación del acceso al ejercicio de poder político, surge el Derecho Electoral, el cual se entenderá a grosso modo como al conjunto de normas jurídicas que regulan la elección de individuos o representantes para ocupar los cargos públicos. También, lo definiremos siguiendo los conceptos del Dr. Alberto del Castillo del Valle como "el conjunto de normas relacionadas con los derechos y obligaciones de los ciudadanos y partidos políticos, que regula la organización de las elecciones, sistemas electorales, sistemas de partidos y la justicia electoral". (Castillo del Catillo, 2000, pp. 109-110)

En una segunda perspectiva se entiende como "el conjunto de normas jurídicas referente a los derechos políticos de los ciudadanos y de los partidos políticos, a través de los cuales se integran los órganos de gobierno encargados de llevar adelante la función de renovación de los Poderes Públicos (función electoral), regulando la organización de elecciones o forma de elegir a los servidores públicos de representación popular, así como la forma de impugnar los actos de la autoridades electorales" (Catillo del Valle, 2000, p.110)

Así, la totalidad de la suma de las voluntades individuales forman un ente colectivo llamado Nación la cual se manifestará mediante un proceso jurídico que marca, en un sentido amplio el acceso a los cargos públicos de representación mediante el otorgamiento de su confianza o sufragando su confianza a través de una simple marca en una boleta, lo que conforma sólo una parte de un complejo y sofisticado proceso político y social regulado jurídicamente y que tiene como finalidad establecer con la mayor claridad y certeza jurídica al o los triunfadores de la contienda, para conformar los poderes políticos de una nación.

Desde un punto de vista sustancial concebiremos al gobierno democrático si bien como un conjunto de reglas "para garantizar la voluntad popular", pero de igual forma entendiendo a este aspecto como al contenido de las decisiones mismas, las cuales deberán de garantizar lo que a cualquier mayoría le está por un lado prohibido y, por el otro, le es obligado a decidir. Desde la perspectiva sustancial, estas normas deberán tender a garantizar el efectivo ejercicio de libertad de los individuos en torno a la manifestación de sus decisiones en función de derechos y obligaciones en los ámbitos individual y colectivo. En palabras de Luigi Ferrajoli (2003) “... En ausencia de límites de carácter sustancial, o sea, de límites a los contenidos de las decisiones legítimas, una democracia puede no-sobrevivir: siempre es posible, en vías de principio, que con métodos democráticos se supriman los mismos métodos democráticos. Siempre es posible, en formas democráticas, o sea, por mayoría, suprimir los mismos derechos político, el 
pluralismo político, la división de los poderes, la representación; en breve, el entero sistema de reglas en el cual consiste la democracia política." (Ferrajoli, 2003, p.229)

Nuestra aproximación conceptual en torno a la democracia moderna o representativa será que esta es una forma de gobierno en la cual todos tenemos la misma posibilidad de participar en la toma de decisiones de carácter público a través de un conjunto de reglas fundamentales, claras y precisas que, por un lado, aseguran la formación de la voluntad popular y que, a su vez, involucran su contenido garantizando lo que a cualquier mayoría le está por un lado prohibido y, por el otro, le es obligado a decidir.

La forma de gobierno democrática representativa fundamentada en un marco normativo que en términos generales establece cómo se organiza el poder político, quién y con qué finalidad y limites lo ejerce, quién participa en formulación de las decisiones colectivas etc. deberá de procurar además la existencia de un sistema de principios ético - normativos vinculados con el ideal de justicia y, circunscribiéndonos a la materia toral de este ensayo a la justicia electoral. Sobre el particular existe una gran discusión, ya que establecer principios generales primero desde el punto de vista del derecho positivo implica un gran debate $y$, en segundo término, pero no por ello menos importante, distinguir, en función de los primeros los valores ético-normativos de la justicia electoral.

Así, los principios y valores ético-normativos de la justicia electoral harán referencia a lineamientos que se procurará seguir con la finalidad de alcanzar el ideal de los justo, de esta manera algunos de estos principios serán: principio de libertad, de equidad, universalidad, de igualdad, objetividad, tutela judicial, principio de imparcialidad, probidad, principio de legalidad, certeza y seguridad jurídica, principio de supremacía constitucional, objetividad jurídica, principio de profesionalismo y excelencia jurisdiccional, independencia jurisdiccional entre otros.

Los principios o valores ético-normativos del derecho electoral y, por ende, de la justicia electoral, enlistados con anterioridad, no pretenden ser los únicos sino por el contrario, marcar un común denominador en lo que respecta al concepto de justicia electoral con la finalidad de enriquecerlos y perfeccionarlos.

La labor del legislador racional debe de ser el procurar no dejar duda acerca del sentido sustancial de la legislación, es decir, de la finalidad y objetivo preciso de la misma, ya que de lo contrario se tendría como consecuencia un ordenamiento jurídico con lagunas o vacios, lo que lleva a buscar solventar esa situación a través de la interpretación jurisprudencial y, a falta de ella, a la aplicación de principios generales de derecho y principios rectores de la justicia electoral.

Por ello, haciendo referencia sólo a los principios generales diremos que acreditándose los supuestos de la existencia de alguna laguna jurídica, contradicción entre normas del mismo ordenamiento jurídico o falta de interpretación jurisprudencial sobre determinado criterio de aplicación normativa, 
los principales ejes rectores o principios fundamentales del derecho electoral $y$, por ende, de la justicia electoral, en los que existe consenso en la doctrina especializada en el tema son esencialmente la legalidad, imparcialidad, equidad, certeza y objetividad, los cuales, de igual manera, en el caso del estado mexicano, son establecidos en el régimen político fundamental y, a su vez, en las legislaciones electorales de todas las entidades federativas.

La aplicación de principios generales de derecho se entenderá que se dará por excepción, ya que la misma Constitución Política de los Estados Unidos Mexicanos y tesis jurisprudenciales han establecido que:

Artículo 16. Nadie puede ser molestado en su persona, familia, domicilio, papeles o posesiones, sino en virtud de mandamiento escrito de la autoridad competente, que funde y motive la causa legal del procedimiento.

A falta expresa de la fundamentación correspondiente se cita la siguiente tesis:

Registro No. 196019 Localización: Novena Época Instancia: Tribunales Colegiados de Circuito Fuente: Semanario Judicial de la Federación y su Gaceta VII, Junio de 1998 Página: 692 Tesis: XI.3o.13 P Tesis Aislada Materia(s): Penal

Principios generales de derecho. No son aplicables cuando exista texto legal expreso sobre determinada situación jurídica.

Si en la sentencia de segunda instancia reclamada, se expresó que se daban por reproducidos los razonamientos del a quo, relacionados con la demostración de los elementos de los delitos que se atribuyeron al ahora quejoso, de la responsabilidad de éste en su comisión y de la legalidad de las sanciones que se le impusieron "en obsequio al principio de economía procesal"; tal proceder es ilegal, puesto que los principios generales de derecho no son aplicables cuando exista texto legal expreso sobre determinada situación jurídica, ya que sobre el particular es determinante el artículo 16 de la Constitución Federal, al imponer la obligación a las autoridades de fundar y motivar debidamente sus actos, lo que implica que, necesariamente, deben exponer en éstos los razonamientos lógicojurídicos tendientes a poner de manifiesto que determinado caso encuadra en determinada hipótesis legal.

\section{Tercer tribunal colegiado del décimo primer circuito}

Amparo directo 264/97. Pedro García Martínez. 2 de octubre de 1997. Unanimidad de votos. Ponente: Óscar Hernández Peraza. Secretario: José Valle Hernández.

De igual forma, la fundamentación toral del poder político consolidado en un Estado Constitucional de Derecho con una forma de gobierno democrática la encontramos en los artículos 39 y 41 de nuestra Constitución Política así, es importante decir que estas reglas se encuentran dispersar a lo largo de una serie de numerales de la misma, como el caso de las Facultades de los poderes de la unión, las facultades de las entidades federativas, entre otras. Sin embargo no es 
motivo de esta investigación analizar a profundidad todo el tema, por lo que nos limitaremos a hacer algunas precisiones de los artículos 39 al 41.

Análisis que se hace partiendo de los comentarios que han realizado algunos constitucionalistas mexicanos, ya que esa es justamente la premisa central: el conocimiento del Estado mexicano desde una óptica constitucional.

\section{Artículo 39}

"La soberanía nacional reside esencial y originariamente en el pueblo. Todo poder público dimana del pueblo y se instituye para beneficio de éste. El pueblo tiene en todo tiempo el inalienable derecho de alterar o modificar la forma de su gobierno".

De la simple lectura de este artículo es interesante deducir algunos conceptos que por sí solos reflejan el andamiaje sobre el que se cimenta el Estado mexicano:

\section{a).- Soberanía popular}

Referirnos a la soberanía es hablar de un concepto de toral importancia para la historia evolutiva del derecho, de la ciencia política y de la propia concepción del estado. Diversos han sido los pensadores que en diferentes épocas han concentrado sus esfuerzos en la investigación y conceptualización del tema.

Ya lo mencionaron los teóricos del estado moderno, a la soberanía debe entendérsele como un concepto ligado a la facultad de tomar decisiones en tres áreas específicas: sistema de gobierno, sistema jurídico y elección de autoridades.

No se trata de un concepto baladí o que deba tomarse con superficialidad infundada. Decir ¿quién es el verdadero legitimado para tomar las decisiones en un Estado? Le ha costado a la humanidad miles de vidas en incontables guerras.

Desde la postura inicial que sustentaba la divinidad de la toma de decisiones, entendida como un monopolio exclusivo de un se supremo concebido como Dios. Postura según la cual, solo Dios es capaz de decidir los destinos de los seres humanos y con ellos los del entorno geográfico en el cual habita. Solo Él es capaz de decidir el destino espiritual, social, económico y político del ser humano.

Concepto que desde hace siglos ha quedado superado y hoy se reduce al terreno espiritual, con ocasión de la separación Iglesia-Estado. Nuestra Constitución política maneja una redacción clara al respecto al afirmar en el párrafo 1 del artículo 130:

"El principio histórico de la separación del Estado y las iglesias orienta las normas contenidas en el presente artículo. Las iglesias y demás agrupaciones religiosas se sujetarán a la ley".

Con ello corroboramos que las afirmaciones sobre la divinidad de la soberanía han sido superadas. La influencia de un ser supremo en la toma de decisiones solo es 
aplicable en el terreno de la individualidad de cada ser humano, de su creencia religiosa y de la importancia que le quiera dar a esa fuerza dictadora de decisiones.

Para nuestra Constitución Política, los asuntos de la humanidad, son asuntos de los hombres, no de la Divinidad. De tal suerte que debe buscarse en otro lugar la fuente generadora de las decisiones en un Estado.

Así las cosas, llego una nueva explicación. La soberanía recae en los hombres, en uno en particular. Tesis que admite como superada la divinidad de la soberanía, pero se la transmite a un solo hombre. Así tuvimos a un Luis XVI quien gobernando despóticamente, afirmó "El Estado soy yo".

Atribuir la legitimación de la soberanía a una sola persona, conlleva el planteamiento natural de resolver la lógica pregunta ¿y quién será ese hombre soberano?, ¿cuál es la razón para que ese hombre se distinga de los demás y se erija en soberano, capaz de decidir el resto de sus "semejantes"?

Preguntas nada sencillas de resolver por qué se atribuía tal poder absoluto. A menudo sucedía que quien se atribuía la potestad soberana ( $y$ decisoria, por consecuencia) es quien lo conquistaba a través de la fuerza, del poderío militar y del sometimiento de sus semejantes a través de la guerra. El hombre con más poder era el soberano, el que tenía la fuerza suficiente para dominar a los demás, para imponer su voluntad y junto con ella sus decisiones. Así las cosas, había una mutación natural de conceptos. De soberanía se pasaba a "El Soberano". De ser un concepto abstracto, pasaba a ser un título personal sujeto de codicia pero sobretodo de sometimiento para sus semejantes.

Si atendemos a las causas iniciales de la Revolución Francesa, nos daremos cuenta que en ellas el pueblo enardecido toma las armas para exigirle a sus soberanos el respeto a sus derechos inalienables e intransferible.

Hecho histórico que pone fin al concepto unipersonal de soberanía para ubicarnos en uno tercero, actual y hasta ahora definitivo: la soberanía popular. Bajo esta premisa, la que comparte nuestro artículo 39 , el verdadero titular en la toma de decisiones es el pueblo, quien en todo momento tiene el imprescriptible derecho de elegir lo que mejor convenga a su propio hacer y entender.

Así, se rompe con una tradición divina y personal (a veces entremezclada) donde la soberanía era patrimonio de un ser humano, heredable y hasta podía cambiar de mando, para situarse en un solo punto inamovible e incuestionable: el pueblo.

De esta manera, el pueblo asume el papel que le corresponde al conquistar la titularidad plena en la toma de decisiones colectivas. Decisiones que van desde la elección de la forma de gobierno, autoridades, representantes populares e incluso del marco normativo que lo habrá de regir (a veces a través de fórmulas directas como el referéndum o el plebiscito). 
La historia de México es rica en la conquista de este derecho. Tan solo en los 200 años de vida independiente nuestra Nación ha pasado por gobernantes soberanos como el caso de Maximiliano de Habsburgo o de Santa Anna al hacerse llamar Alteza Serenísima, a verdaderas luchas sociales que reposicionan a la soberanía en su lugar adecuado: el pueblo.

Específicamente la Revolución Mexicana de 1910, antecedente inmediato de nuestra actual Constitución Política, es en sí misma una expresión de soberanía popular en la que el pueblo tomaba las armas para exigir el reconocimiento de sus más elementales derechos. Lógico es entender que siendo esto así, nuestra Constitución Política recogiera en su texto todas esas expresiones soberanas que en el campo de batalla se hicieron valer.

Así las cosas, hoy nos resulta fácil entender, comentar y defender conceptos como el que se analiza. Sin embargo tiene un origen histórico, una justificación teórica y unos antecedentes formales sumamente profundos que nos deben llevar a dimensionarla en su justo medio, dándole la importancia que ella requiere.

Actualmente toda sociedad democrática se cimenta en la soberanía popular, la nuestra es la excepción. De tal suerte que el paso siguiente es desarrollar los canales adecuados para que esa sociedad pueda expresarse libremente y de manera clara, recogiendo la pluralidad de ideas y expresiones que es lógico existan en su interior, pero siempre con la plena defensa de su propia existencia.

La soberanía debe considerarse en dos aspectos, uno interno y el otro externo. El interno viene a ser firme, inamovible, inquebrantable, relacionado de manera directa con el territorio, la población y el gobierno de un Estado. Su vigencia se asegura a través de su firmeza.

Mientras que el segundo, el externo se materializa en las relaciones exteriores que cada Estado mantiene con sus iguales. En este caso en particular puede ser flexible, negociable, laxa y permisiva de una serie de situaciones; todo depende del tipo de acuerdo internacional a que lleguen los Estados. Así, tenemos a Estados soberanos que han decidido comprometer su soberanía con otro Estado a cambio de beneficios especiales, normalmente unidos a seguridad y protección: El Vaticano, Puerto Rico, por citar algunos.

Tanto de manera externo, como interna, la soberanía no deja de ser una expresión de decisión popular. El baremo que mide y legitima las decisiones tomadas tanto en uno como en otro sentido es el poder público.

En palabras de Carpizo (1991, p. 23), el uso del concepto "pueblo" es evocar el pensamiento de Rousseau, cuando se refiere a las libertades y al anhelo de los hombres por alcanzar su felicidad y realizar su destino. En este sentido, el autor transcribe a Castillo Velasco al establecer: 
"La soberanía es la potestad suprema que nace de la propiedad que el pueblo y el hombre tienen de sí mismos, de su libertad y de su derecho... Reside, dice el artículo constitucional, y no residió, aunque porque para el establecimiento de un gobierno delega el pueblo algunas de las facultades de su soberanía, ni las delega todas, ni delega algunas irrevocablemente. Encarga el ejercicio de algunas de esas facultades y atribuciones a aquellos funcionarios públicos que establece; pero conservando siempre la soberanía, de manera que ésta reside constantemente en el pueblo. " (Carpizo, 1991, p.23)

Al mencionar que la soberanía reside en el pueblo, se quiere señalar que México, desde que es nación independiente tiene una tradición que ayuda a encontrar a las generaciones presentes su peculiar modo de vivir. México es una unidad que a través de la historia se ha ido formando, y que como nación tiene una proyección hacia el futuro, pero sin olvidarse de su pasado y de su presente.

Finalmente, al referirnos al término "originariamente", la Constitución está haciendo alusión a que jamás ha dejado de residir en el pueblo; aunque la fuerza haya dominado, no por ello prescribe a su favor. Mientras que "esencial", porque en todo momento el pueblo es soberano; nunca delega su soberanía, únicamente nombra a sus representantes, que están bajo sus instrucciones y mando.

\section{b).- El pueblo como fuente única de todo poder público}

Segunda idea que desarrolla el numeral en comento. Al ser el pueblo el titular indiscutible en la toma de decisiones de los asuntos públicos, está claro que no los podrá conducir de manera directa, sino que lo hará a través de los representantes idóneos que para el caso elija. Razonamiento que legitima la existencia de un poder surgido del pueblo, por el pueblo y para el pueblo: el poder público.

A través del poder público el pueblo es capaz de tomar todo tipo de decisiones, en ejercicio pleno de su soberanía. Se nombra y constituye para la toma de decisiones que habrán de afectar a la colectividad.

Atendiendo a este nivel de importancia, en todo momento el pueblo debe ser especialmente cuidadoso en la integración de su poder público, así como en la elección de los representantes que habrán de tomar decisiones en su nombre.

Aseveración que claramente se correlaciona con el artículo 41 constitucional al señalar en su párrafo primero:

"El pueblo ejerce su soberanía por medio de los Poderes de la Unión, en los casos de la competencia de éstos, y por los de los Estados, en lo que toca a sus regímenes interiores, en los términos respectivamente establecidos por la presente Constitución Federal y las particulares de los Estados, las que en ningún caso podrán contravenir las estipulaciones del Pacto Federal".

Señala Burgoa, que este artículo es indispensable para entender la dimensión constitucional de la soberanía popular. Transformada en este caso en la facultad 
legitimadora de generar los Poderes de la Unión como mecanismos para ejercer la soberanía, es decir el poder público a que alude el artículo 39.

¿Cuál es la importancia del poder público?

Si el pueblo es el titular de la soberanía, cosa que ya ha sido desarrollada en líneas anteriores, esto no es suficiente para acabar la fórmula democrática de toma de decisiones. El pueblo, a pesar de su soberanía, goza de una importante limitante: que no es capaz de decidir solo, ni de tomar todas las decisiones a la vez. Impensable sería construir un foro donde quepan los 112 millones de mexicanos para que libremente expresemos nuestro punto de vista.

Esa imposibilidad se subsana a través de la creación del poder público, entendido como el representante del pueblo, el legitimado naturalmente por ella para decidir en su nombre y en su beneficio. Esta es la importancia del poder público: viene a ser el catalizador que todo pueblo necesita para ejercer su soberanía, sin él no es posible ejercicio democrático alguno.

Sin el poder público, no tiene caso tener soberanía. Su ausencia significaría el goce de un derecho inutilizado porque carece de los medios especiales para su peno ejercicio.

\section{c).- Inalienable derecho de modificar la forma de su gobierno}

Finalmente, este postulado termina de cerrar el ciclo natural de la soberanía, su titular es del pueblo, de ella emana y a ella vuelve.

Ninguna soberanía es completa sino desarrolla la capacidad propia para que por sí sola pueda tomar decisiones que lleven a replantear los mecanismos de integración del Estado, las veces que sean necesarias. Es una característica que nuestra propia Constitución Política establece al contemplar mecanismos suficientes para reformarse la veces que sea necesaria, con el ánimo de mantenerla actualizada, junto con el Estado y la voluntad popular, antes que pierda su vigencia y su consecuente legitimidad.

En opinión de Carpizo (1991), la intención del constituyente fue vincular esta última frase del artículo 39, con el artículo 135, que contiene el procedimiento para reformar la Constitución. El pueble tiene en todo momento el derecho de alterar o modificar la forma de su gobierno, pero a través del propio derecho; a través de los cauces que indica la Constitución, ya que el derecho no otorga la facultad para abolirlo; en otras palabras, el derecho a la revolución es un derecho metajurídico.

\section{Artículo 40}

"Es voluntad del pueblo mexicano constituirse en una República representativa, democrática, federal, compuesta de Estados libres y soberanos en todo lo concerniente a su régimen interior; pero unidos en una federación establecida según los principios de esta ley fundamental". 
A continuación se realiza un análisis estructural de este numeral constitucional, en razón a su importancia y al impacto directo que tiene en el presente tema de investigación.

\section{a).- La forma republicana de gobierno}

Se trata del primer elemento que enuncia este numeral. Puede decirse que es republicano un Estado en el cual la jefatura del Estado no se transmite por vía hereditaria ni es desempeñada con carácter vitalicio (Lucas Verdú, 1981), y dentro del cual se observan una serie de valores y conductas acordes al propio sistema republicano. Si junto a la forma republicana de gobierno se define un Estado como democrático, se entiende que la jefatura del Estado no solo no es vitalicia ni hereditaria, sino que además se establece y se renueva con una participación relativamente directa del pueblo.

En palabras de Carbonell (1998), el republicanismo, tanto como práctica del gobierno republicano y como ideología que lo sustenta, implica una serie de valores que se corresponden con varias consecuencias concretas dentro de la organización política del Estado constitucional. Algunos de estos supuestos ideológicos de la República (Cabo, 1997) son:

1.- Transigencia.- se trata de un sistema que acepta el libre juego de clases en la búsqueda del poder político y se crean mecanismos de conciliación; se institucionaliza el conflicto, y con ello la transigencia.

2.- Laicismo.- la República es la verdadera alternativa que trata de secularizar por completo la tolerancia a todo tipo de creencia religiosa (si es que la hubiera) la vida social y la política de Estado.

3.- Libertad e igualdad.- Valores que han sido incorporados desde 1789 en prácticamente todos los sistemas jurídicos. Un Estado republicado solo puede entenderse en un entorno de libertades hacia el individuo. Por su parte, la igualdad permite la participación de todos los ciudadanos en el proceso político, de ello deriva la noción jurídica de soberanía y se da lugar al sistema representativo, a la regulación de toda problemática electoral y a la determinación del específico papel del parlamento.

4.- la cultura como exigencia.- Para que una república pueda consolidarse, es necesario que eduque a sus habitantes dentro de los principios republicanos. Es en el frente educativo donde los valores republicanos obtienen alguna posibilidad de permanencia frente a los intereses de las viejas clases dominantes. La práctica política de la República, el ejercicio de los derechos fundamentales requiere que los ciudadanos aprecien los valores que la sustentan y que estén en posibilidades de defenderlos y hacerlos permanentes. (Vázquez, 1997)

El hecho de que nuestra Constitución Política haya escogido la república como forma de gobierno, tiene que ver con el concepto de soberanía que recoge en el artículo 39 de la misma, y del que ya se han hecho algunos comentarios.

Si la soberanía, tal y como lo señala el artículo 39, es nacional y popular, eso impensable que puedan contemplarse mecanismos vitalicios o consanguíneos de transmisión de ella entre quienes detentan el poder público. Está claro que en un 
desarrollo lógico del artículo 39, tenía que generarse un artículo 40 que acabara por darle forma a la conceptualización nacional y popular de la soberanía. Ese mecanismo es la creación de la forma de gobierno republicana, que se caracteriza, principalmente por mantener mecanismos de participación pública para todos sus ciudadanos en la estrategia de toma de decisiones.

\section{b).- Gobierno representativo}

En palabras de Montesquieu (1995), la gran ventaja de los representantes es que tienen capacidad para discutir los asuntos, el pueblo en cambio no está preparado para esto, lo que constituye uno de los graves inconvenientes de la democracia.

De manera lógica, se complementan los artículos 39 y 40 , el primero sugiere mecanismos de democracia directa al establecer que el pueblo toma decisiones; mientras que el 40 matiza esta afirmación al establecer que el pueblo no puede participar directamente en la toma de decisiones políticas, por lo que debe escoger a quienes en su nombre formen la voluntad popular, supuesto que legitima de manera clara e indubitable la representatividad.

A través de la representación es como se materializa la soberanía popular. Son ellos quienes se erigen como depositarios de la voluntad popular, ya que son seleccionados por ella y su labor siempre será de frente a ella misma.

Nuestra República es representativa porque solo a través de esta vía es posible que una verdadera república funcione. Este carácter representativo implica que toda la producción normativa queda en manos de los poderes públicos representantes del pueblo (Tena, 1990).

Sin embargo, los representantes no se encuentran sometidos a mandato imperativo; es decir, representan a toda la nación, no a un grupo de electores o a una región determinada, de modo que quienes los votaron no pueden revocar su competencia. Si este concepto lo llevamos al derecho civil, es lógico entender que el contrato de mandato contiene la cláusula de revocación al mandatario cuando ha dejado de cumplir, o cumple indebidamente el encargo que el mandante le ha conferido, incluso cabe la posibilidad de indemnización por daños y perjuicios.

En el caso del Derecho Constitucional no es así. El pueblo, que es el soberano, tiene la facultad de elegir libremente a sus mandatarios, pero una vez nombrados se encuentra imposibilitado para revocarles su nombramiento, sancionarlos por incumplir o reclamarles indemnización alguna por concepto de daños y perjuicios. Electo el representante popular, se erige en representante de la soberanía que lo ha nombrado, en garante de la presencia popular a la cual representa.

\section{c).- Estado democrático}

Definir el término democracia es de lo más complejo que se pueda plantear. Nuestra propuesta es partir de lo establecido en el artículo de la Constitución Política al establecer: 
"considerando a la democracia no solamente como una estructura jurídica y un régimen político, sino como un sistema de vida fundado en el constante mejoramiento económico, social y cultural del pueblo".

La democracia reviste un papel esencial para el régimen constitucional, a través de ella se legitima la Constitución y se le permite obtener su cualidad normativa (Aragón, 1989). Tal legitimación se produce en dos momentos: cuando se crea la constitución, ya que la democracia legitima a las Constituciones creadas por el pueblo soberano, y en la organización del Estado, asegurando conductos democráticos de expresión de la voluntad popular y otra serie de condiciones necesarias para la realización de la libertad y de la igualdad de los hombres.

Tener un Estado democrático implica el cumplimiento de una serie de exigencias (Carbonell, 1998):

1.- La creación de una serie de jerarquías entre las distintas autoridades públicas, para generar los rangos correspondientes que lleven a ubicar en primer término a los órganos de representación popular electos democráticamente a través del sufragio universal y directo. Por eso sabemos que en México la máxima tribuna del país es la del Congreso de la Unión, porque son nuestros naturales representantes populares electos bajo los principios democráticos de sufragio universal y directo.

2.- La potestad superior de creación normativa debe recaer en el órgano que tenga el máximo grado posible de representatividad en tanto su composición deriva de la elección popular.

Luego entonces, un Estado democrático garantiza la adecuada toma de decisiones a través de los representantes populares que para ello fueron electos.

Responsabilidad que conlleva a la inevitable exigencia que tiene cada Estado de asegurarse los mejores mecanismos de selección de sus representantes populares. Para el caso de México, se ha establecido que será a través del sufragio universal, libre, directo y secreto de todos los ciudadanos de la República. Construir un sistema democrático es el permanente reto de todos los ciudadanos de la República, al igual que de todos sus actores: partidos políticos, instituciones, Estado, sindicatos, etc.

Mientras más sólido sea el sistema democrático de un Estado, más sólidas y legítimas serán las decisiones que este tome, ya que lo harán los verdaderamente legitimados para ello.

Uno de los propósitos centrales de esta investigación es analizar los mecanismos de elección del Estado mexicano. De tal suerte que este planteamiento conceptual y constitucional hasta ahora realizado, sirve de base para realizar el análisis jurídico que se ha planteado a las legislaciones locales.

\section{d).- Sistema federal}

Aunque este es uno de los temas centrales de esta investigación, anticiparemos algunos comentarios al respecto. 
Históricamente el federalismo llega a México con la Constitución de 1824, influenciada por el Sistema Norteamericano, que así fue concebido y constituido.

Nuestra actual Constitución Política señala claramente que somos una nación compuesta de Estados Libres y Soberanos, pero unidos en una Federación. Acto seguido enlista a todas las Entidades Federativas que la integran y termina por señalar la necesidad de una sede de los poderes federales, el Distrito Federal.

A lo largo de diversos artículos, podemos apreciar que nuestra Constitución señala las facultades de la Federación, al atribuírselas a cada uno de los poderes. Posteriormente señala las prohibiciones de las Entidades Federativas, bajo un principio general del derecho: a ellas, todo lo no prohibido les está permitido.

Constituirse como una nación federal, implica aprender a convivir en diversidad, con pluralidad de leyes y autoridades, alineadas a ciertos principios generales que les son comunes; pero, especialmente conlleva el claro respeto a las disposiciones de la Constitución Federal.

\section{Artículo 41}

"El pueblo ejerce su soberanía por medio de los Poderes de la Unión, en los casos de la competencia de éstos, y por los de los Estados, en lo que toca a sus regímenes interiores, en los términos respectivamente establecidos por la presente Constitución Federal y las particulares de los Estados, las que en ningún caso podrán contravenir las estipulaciones del Pacto Federal".

Para entender este artículo, primeramente deberemos hacer notar la diferencia que existe entre el Estado y la forma de gobierno, ya que no debe confundirse estas entidades, ni tampoco creerse que sean sinónimos. El Estado es "una institución pública dotada de personalidad jurídica, mientras que el gobierno es el conjunto de órganos estatales que ejercen las funciones en que se desarrolla el poder público perteneciente a la entidad estatal". (Suprema Corte de Justicia, 2006)

Si nos remitimos a los antecedentes que dieron origen a nuestra Constitución, reconoceremos y entenderemos ¿por qué el congreso constituyente al crear la norma suprema del país decide que el pueblo sea quien ejerce la soberanía del pueblo?, y ¿cómo es que el pueblo decide ejercer su soberanía a través de los poderes de la Unión en cuanto a la competencia Federal y a través de los Estados respecto a sus correspondientes competencias?

La razón es histórica ya que nuestra Constitución sigue un modelo liberal, el cual según Justo Sierra es:

"aquel modelo que proviene de la fusión de las ideas liberales tanto estadounidenses contenidas en su constitución como las ideas francesas contenidas en los principios de la llustración". 
De este artículo claramente se desprende que las entidades federativas no son soberanas sino autónomas, y que existe una división de competencias entre los dos órdenes que la propia Constitución crea y que le están subordinados: el de la federación y el de las entidades federativas. La nota característica del Estado federal, que acepta el artículo 41, es la descentralización política.

La titularidad de la soberanía, como ya se ha dicho antes, la tiene el pueblo y es ejercida a través de los Poderes de la Unión, en lo referente al ámbito federal y a los Estados en lo que respecta a sus regímenes interiores. Siendo entonces que las entidades federativas se gobiernan con absoluta autonomía siempre que no se trate de facultades reservadas al gobierno federal y no se contravengan disposiciones del pacto federal.

Los estados y la federación deberán organizarse de acuerdo a lo contenido por los artículos 115 en lo que refiere a los Estados y en los demás contemplados en la Constitución en lo que refiere a las facultades que tendrá la Federación, existiendo entre ambas coincidencia e igualdad de decisiones jurídico políticas fundamentales, principio que se deriva de los artículos 40 y 115 constitucionales (Diccionario Jurídico Mexicano, 1998).

Sin embargo, tal establece también un límite para el ejercicio de los Estados, el no contravenir el pacto federal. Es decir que por ningún motivo los estados vía sus ordenamientos o las decisiones de sus órganos internos, pueden alterar la naturaleza del pacto federal, esto es, el querer o pretender en uso de su autonomía escindirse o desprenderse de la federación.

De entre las obligaciones que establece el pacto federal, está el de permanecer en unión con la Federación, por lo que su gobierno debe sujetarse a los mandatos de la norma suprema, de manera que si las leyes o los actos de las autoridades estatales resulten contrarios a las disposiciones constitucionales, estas últimas prevalecerán sobre aquellas. Los Estados a través del pacto federal se subordinan a la Federación, al no actuar fuera de los límites de su competencia.

Del principio anteriormente referido las autoridades de las entidades federativas no se encuentran subordinadas a las federales, si no que dentro de su competencia son libres, o autónomas. Sin embargo para evitar que la autonomía degenere en individualismo o anarquía, se deben considerar varios principios, que se enlistan de manera enunciativa: principio de subsidiariedad; de participación o unidad; de cooperación; de garantías (Diccionario Jurídico Mexicano, 1998).

Siguiendo con la lectura de Carpizo (1991, p. 36-37), estableceremos que el Estado federal mexicano sustenta los siguientes principios: 
a).- las entidades federativas son instancia decisoria suprema dentro de su competencia (artículo 40).

b).- Entre la federación y las entidades federativas existe coincidencia de decisiones fundamentales (artículo 40 y 115).

c).- Las entidades federativas se dan libremente su propia Constitución en la que organizan su estructura de gobierno, pero sin contravenir el pacto federal inscrito en la Constitución general, que es la unidad del Estado federal (artículo 41).

d).- Existe una clara división de competencia entre la federación y las entidades federativas: todo aquello que no esté expresamente atribuido a la federación es competencia de las entidades federativas (artículo 124).

Algunas características de esta división de competencias son:

a).- Existen las facultades implícitas, pero no han tenido mayor desarrollo; la federación ha adquirido nuevas facultades a través de reformas constitucionales.

b).- Dentro del texto constitucional se encuentran facultades que pueden ser: atribuidas a la federación, atribuidas a las entidades federativas, prohibidas a la federación, prohibidas a las entidades federativas.

c).- Existen facultades coincidentes que son aquellas que tanto la federación como las entidades federativas pueden realizar.

d).- Existen facultades coexistentes que son aquellas en que una parte de la misma facultad compete a la federación y la otra a las entidades federativas.

e).- Existen facultades de auxilio que son aquellas en que una autoridad ayuda a otra por disposición constitucional.

f).- No existen las facultades concurrentes.

g).- La jurisprudencia de la suprema Corte de Justicia de la Nación modifica los términos de la división de competencias establecido en el artículo 124, específicamente en materia impositiva.

Por otro lado, brevemente comentaremos la expresión Constitucional: “...la renovación de los poderes legislativo y Ejecutivo se realizarán mediante elecciones libres, auténticas y periódicas".

Este párrafo constitucional se inserta hasta la reforma constitucional de 1996. Al tener México una forma de gobierno de democracia indirecta es necesario elevar a rango constitucional la forma en la que esta se llevará a cabo y los principios que debe seguir la misma. Al haberse incluido este párrafo significa que los órganos del Estado deberán sujetarse al mismo, y quitar cualquier obstáculo que impida que las elecciones no se lleven a cabo en contra de estos principio, hecho que a bien decir resulta crucial en la historia jurídica de nuestro país.

Con ello se legitiman los procesos electorales, entendidos como monopolios de acceso al poder, al tiempo de ser monopolios de expresión soberana en la toma de decisiones por parte del pueblo. Acceso al poder que debe hacerse a través de los partidos políticos. De ahí que la Constitución literalmente establezca en su artículo 41: 
"Los partidos políticos son entidades de interés público; la ley determinará las formas específicas de su intervención en el proceso electoral. Los partidos políticos tienen como fin promover la participación del pueblo en la vida democrática, contribuir a la integración de la representación nacional y como organizaciones de los ciudadanos, hacer posible el acceso de éstos al ejercicio del poder público, de acuerdo con los programas, principios e ideas que postulan y mediante el sufragio universal, libre, secreto y directo.

Los partidos políticos tendrán derecho al uso en forma permanente de los medios de comunicación social, de acuerdo con las formas y procedimientos que establezca la ley.

En los procesos electorales federales los partidos políticos nacionales deberán contar, en forma equitativa, con un mínimo de elementos para sus actividades tendientes a la obtención del sufragio popular.

Los partidos políticos nacionales tendrán derecho a participar en las elecciones estatales y municipales."

Con ello se elevan a rango constitucional los partidos políticos, otorgándoles en su fracción I la naturaleza jurídica de interés público. Estableciéndose, por exclusión, que estos jamás podrán ser asociaciones privadas, como lo es en el derecho anglosajón, ni órganos del Estado como alguna vez se consideraron en Alemania.

En la actualidad cada partido político es algo más que entidades de interés público. Autores como Daniel Montero Zendejas (1991 p. 556), que al hablar del tema de los partidos políticos en su obra Derecho Político Mexicano nos refiere:

"En la época moderna el protagonista del nuevo príncipe no podría ser un héroe personal, sino un partido político, determinado partido que en cada momento y en las diversas relaciones internas de las diferentes naciones intenta creare un nuevo tipo de Estado"

Los partidos políticos son la expresión de un grupo social, y además como bien lo refiere Ignacio Burgoa (1998):

"El partido político, es el laboratorio donde se formulan las directrices de un gobierno, cuyos funcionarios las desarrollan si, habiendo sido postulados por él, obtienen la mayoría de sufragios. Sin los partidos políticos la vida democrática estaría desorganizada y sujeta a la improvisación en la elección de los referidos titulares." (Burgoa, 1998, p.333).

Otro aspecto importante, es el que se refiere a los fines que se les han atribuido, como promover la participación del pueblo en la vida democrática; contribuir a la representación nacional y como organización de ciudadanos, situación que es también la respuesta a la garantía de asociación consagrada en la parte dogmática de la Constitución.

En cuanto al primero se refiere, el promover la participación del pueblo en la vida democrática es una función social, entre los que destacan acciones como la 
representación de intereses y legitimación del sistema político, al ser los partidos políticos entidades de interés público, y la forma en la que los gobernados pueden acceder a un cargo de representación público es lógico que se cumplan primeramente con funciones sociales, ya que son los instrumentos políticos que permiten que el pueblo continúe ejerciendo su soberanía.

La segunda función de los partidos políticos: contribuir a la integración nacional, es una función de carácter institucional, ya que los partidos políticos mediante su actuar cumplen con la función de permitir organizar los poderes públicos. Ya que como es el caso de México los miembros del poder legislativo y ejecutivo se eligen a través de partidos políticos y este ultimo poder (el ejecutivo) es quien elige a los más altos funcionarios del poder Judicial de la Nación.

La última función: hacer posible el acceso a los ciudadanos al ejercicio del poder público mediante el sufragio universal, libre, secreto y directo, es una función que permite a los ciudadanos garantizar el ejercicio de su soberanía a través del derecho del voto, que es un derecho por demás personal, el cual obliga a los órganos de gobierno a respetar que sea efectuado con las características de que sea emitido libremente, es decir, sin coacción alguna, secreto ya que se trata de un derecho personalísimo otorgado al ciudadano cuando este reúne el carácter de tal, y directo, es decir que nadie puede hacerlo valer por otra persona.

Estas características del sufragio contenidas a nivel constitucional, obedecen a la historia social y política del país, a la necesidad de otorgarle a los ciudadanos la certeza de que el derecho a elegir a sus representantes es un derecho personal y autónomo.

Se fija así también en el mismo artículo, la forma en que se realizará su financiamiento público para el sostenimiento de sus actividades, facultada que será calculada por el Órgano Superior de Dirección del Instituto Federal Electoral. Mismo organismo que se encargará de la organización de las elecciones Federales cuyos principios rectores serán; la certeza, la legalidad, imparcialidad y objetividad.

El Instituto Federal electoral será una autoridad que se integrará por un Consejero Presidente y ocho consejeros electorales, concurriendo con voz pero sin voto, los consejeros del Poder Legislativo, los representantes de los partidos políticos y un Secretario Ejecutivo estableciendo en el mismo texto constitucional sus funciones de manera general y el periodo de su encargo.

Así, México como un Estado Constitucional de Derecho y una entidad federada procurará consolidar su forma de gobierno, que en este caso es la democrática, desde los puntos de vista tanto forma como sustancial. 
Uno de los pilares fundamentales para esa consolidación es lo referente a la constitución y organización del poder político, para tal efecto, el contar con legislaciones electorales sólidas en sus contenidos es crucial.

La generación de certeza jurídica en esta creación, constitución y organización del poder político fortalece los cimientos del Estado Constitucional de Derecho y, en este tenor, contar con legislaciones electorales que, en el ejercicio de su aplicación no sólo establezcan un diseño democrático sino que además procuren, desde lo sustancial, a la justicia es base fundamental.

En este sentido, se presenta un análisis de las legislaciones electorales vigentes en las entidades federativas mostrando un comparativo entorno al establecimiento tanto de principios generales de derecho como de principios rectores de la función electoral con la finalidad de tener una referencia vigente de los criterios sustanciales en el desempeño de la labor electoral, tanto administrativa como jurisdiccional.

Las fuentes de consulta legislativa para este comparativo fueron la página de la Cámara de Diputados en la referencia de Leyes y Poderes Estatales: http://www.diputados.gob.mx/LeyesBiblio/gobiernos.htm y, de igual forma, las páginas de los Congresos.

\begin{tabular}{|l|l|l|}
\hline \multicolumn{3}{|c|}{ ANÁLISIS LEGISLATIVO ELECTORAL COMPARADO } \\
POR ENTIDAD FEDERATIVA
\end{tabular}




\begin{tabular}{|c|c|c|}
\hline & & $\begin{array}{l}\text { la certeza, legalidad, } \\
\text { independencia, imparcialidad } \\
\text { y objetividad serán principios } \\
\text { rectores. } \\
\text { Artículo 116. Fracción IV. Las } \\
\text { Constituciones y leyes de los } \\
\text { Estados en materia electoral } \\
\text { garantizarán que: b) En el } \\
\text { ejercicio de la función electoral, } \\
\text { a cargo de las autoridades } \\
\text { electorales, sean principios } \\
\text { rectores los de certeza, } \\
\text { imparcialidad, independencia, } \\
\text { legalidad y objetividad; }\end{array}$ \\
\hline $\begin{array}{l}1 \\
\text { Aguascalientes }\end{array}$ & $\begin{array}{l}\text { Art. } 4 \text { Parrafo I. La } \\
\text { interpretación de la ley se } \\
\text { hará conforme a los criterios } \\
\text { gramatical, sistemático y } \\
\text { funcional. A falta de } \\
\text { disposición expresa, se } \\
\text { aplicarán los principios } \\
\text { generales del derecho. }\end{array}$ & $\begin{array}{l}\text { ARTÍCULO } 4^{\circ} \text {. EI Sistema } \\
\text { Estatal Electoral se regirá por } \\
\text { los principios rectores de } \\
\text { certeza, legalidad, } \\
\text { independencia, imparcialidad, } \\
\text { definitividad, objetividad, } \\
\text { autonomía y austeridad. }\end{array}$ \\
\hline $\begin{array}{l}2 \\
\text { California }\end{array}$ & $\begin{array}{l}\text { ARTíCULO 8.- A falta de } \\
\text { disposición expresa en esta } \\
\text { Ley, se estará a lo dispuesto } \\
\text { en la Constitución Federal, } \\
\text { en la Constitución del Estado, } \\
\text { en los criterios obligatorios } \\
\text { que dicte el Tribunal } \\
\text { Electoral, la Jurisprudencia } \\
\text { del Tribunal Electoral del } \\
\text { Poder Judicial de la } \\
\text { Federación, en los acuerdos } \\
\text { del Consejo General dictados } \\
\text { dentro del ámbito de su } \\
\text { competencia, y a los } \\
\text { principios generales del } \\
\text { derecho. }\end{array}$ & $\begin{array}{l}\text { ARTíCULO 1.- Las } \\
\text { disposiciones de esta Ley son } \\
\text { de orden público, de } \\
\text { observancia general en el } \\
\text { Estado de Baja California y } \\
\text { tienen por objeto dar certeza, } \\
\text { legalidad, independencia, } \\
\text { imparcialidad y objetividad al } \\
\text { ejercicio de la función pública } \\
\text { electoral. }\end{array}$ \\
\hline $\begin{array}{ll}3 & \text { Baja } \\
\text { California Sur }\end{array}$ & $\begin{array}{l}\text { ARTíCULO } 5^{\circ} \text {.- La } \\
\text { interpretación de la presente } \\
\text { Ley se hará conforme a los } \\
\text { criterios gramatical, } \\
\text { sistemático y funcional, } \\
\text { atendiendo a lo dispuesto en } \\
\text { el último párrafo del artículo }\end{array}$ & $\begin{array}{l}\text { ARTíCULO } \mathbf{2}^{\circ} \text {.- La organización } \\
\text { de las elecciones es una } \\
\text { función estatal que se realiza a } \\
\text { través de un organismo público } \\
\text { autónomo, de carácter } \\
\text { permanente, denominado } \\
\text { Instituto Estatal Electoral de }\end{array}$ \\
\hline
\end{tabular}




\begin{tabular}{|c|c|c|}
\hline & $\begin{array}{l}14 \text { de la Constitución Política } \\
\text { de los Estados Unidos } \\
\text { Mexicanos. }\end{array}$ & $\begin{array}{l}\text { Baja California Sur; dotado de } \\
\text { personalidad jurídica y } \\
\text { patrimonio propio, en cuya } \\
\text { integración participan el Poder } \\
\text { Legislativo del Estado, los } \\
\text { Partidos Políticos Nacionales y } \\
\text { Estatales y los ciudadanos en } \\
\text { los términos que ordene esta } \\
\text { Ley. La certeza, legalidad, } \\
\text { independencia, equidad, } \\
\text { imparcialidad y objetividad } \\
\text { serán principios rectores en el } \\
\text { ejercicio de esta función. }\end{array}$ \\
\hline 4 Campeche & $\begin{array}{l}\text { Art. 3.- La aplicación de las } \\
\text { normas de este Código } \\
\text { corresponde al Instituto } \\
\text { Electoral del Estado de } \\
\text { Campeche, a la Sala y } \\
\text { Juzgados Electorales del } \\
\text { Poder Judicial del Estado y al } \\
\text { Congreso del Estado, en sus } \\
\text { respectivos ámbitos de } \\
\text { competencia. La } \\
\text { interpretación se hará } \\
\text { conforme a los criterios } \\
\text { gramatical, sistemático y } \\
\text { funcional atendiendo a lo } \\
\text { dispuesto en el último } \\
\text { párrafo del artículo } 14 \text { de la } \\
\text { Constitución Política de los } \\
\text { Estados Unidos Mexicanos. }\end{array}$ & $\begin{array}{l}\text { Art. 147.- Todas las actividades } \\
\text { del Instituto Electoral del Estado } \\
\text { de Campeche se regirán por los } \\
\text { principios de certeza, } \\
\text { imparcialidad, independencia, } \\
\text { legalidad y objetividad. }\end{array}$ \\
\hline 5 Coahuila & $\begin{array}{l}\text { Artículo } 5 \text { Numeral 2. La } \\
\text { interpretación se hará } \\
\text { conforme a los criterios } \\
\text { gramatical, sistemático y } \\
\text { funcional, atendiendo a lo } \\
\text { dispuesto en el último párrafo } \\
\text { del artículo } 155 \text { de la } \\
\text { Constitución }\end{array}$ & $\begin{array}{l}\text { Artículo 7; Numeral 1, inciso } \\
\text { b) Los ciudadanos que } \\
\text { pretendan actuar como } \\
\text { observadores deberán señalar } \\
\text { en el escrito de solicitud los } \\
\text { datos de identificación personal } \\
\text { anexando fotocopia de su } \\
\text { credencial para votar con } \\
\text { fotografía, y la manifestación } \\
\text { expresa de que se conducirán } \\
\text { conforme a los principios de } \\
\text { imparcialidad, objetividad, } \\
\text { certeza y legalidad, y sin } \\
\text { vínculos a partido u } \\
\text { organización política alguna. }\end{array}$ \\
\hline
\end{tabular}




\begin{tabular}{|c|c|c|}
\hline & & $\begin{array}{l}\text { Artículo 68.- Numeral } 2 . \\
\text { Todas las actividades del } \\
\text { Instituto se regirán por los } \\
\text { principios de certeza, } \\
\text { legalidad, independencia, } \\
\text { imparcialidad y objetividad. } \\
\\
\text { Artículo 72.- Numeral 1. El } \\
\text { Consejo General es el órgano } \\
\text { superior de dirección, } \\
\text { responsable de vigilar el } \\
\text { cumplimiento de las } \\
\text { disposiciones constitucionales y } \\
\text { legales en materia electoral, así } \\
\text { como de velar porque los } \\
\text { principios de certeza, } \\
\text { legalidad, independencia, } \\
\text { imparcialidad y objetividad } \\
\text { guíen todas las actividades del } \\
\text { Instituto. }\end{array}$ \\
\hline 6 Colima & $\begin{array}{l}\text { ARTICULO 40.- Párrafo } \\
\text { Segundo La interpretación se } \\
\text { hará conforme a los criterios } \\
\text { gramatical, sistemático y } \\
\text { funcional, atendiendo a lo } \\
\text { dispuesto en el último párrafo } \\
\text { del artículo } 14 \text { de la } \\
\text { CONSTITUCIÓN FEDERAL. }\end{array}$ & $\begin{array}{l}\text { ARTICULO 3o.- Párrafo } \\
\text { Segundo La certeza, } \\
\text { legalidad, independencia, } \\
\text { imparcialidad y objetividad, } \\
\text { serán principios rectores en el } \\
\text { ejercicio de dicha función. }\end{array}$ \\
\hline 7 Chiapas & $\begin{array}{l}\text { Artículo 2. La aplicación de } \\
\text { las disposiciones de este } \\
\text { Código corresponde al } \\
\text { Instituto de Elecciones y } \\
\text { Participación Ciudadana, a la } \\
\text { Comisión de Fiscalización } \\
\text { Electoral, al Tribunal de } \\
\text { Justicia Electoral y } \\
\text { Administrativa del Poder } \\
\text { Judicial del Estado, a la } \\
\text { Fiscalía Electoral y al } \\
\text { Congreso del Estado, en el } \\
\text { ámbito de sus respectivas } \\
\text { competencias, quienes } \\
\text { tendrán la obligación de velar } \\
\text { por su estricta observancia y }\end{array}$ & $\begin{array}{l}\text { Artículo 134. La certeza, } \\
\text { seguridad, veracidad, } \\
\text { legalidad, independencia, } \\
\text { imparcialidad y objetividad, } \\
\text { serán los principios rectores del } \\
\text { proceso electoral que regirán la } \\
\text { actuación de las autoridades } \\
\text { administrativas electorales en el } \\
\text { ejercicio de sus atribuciones. }\end{array}$ \\
\hline
\end{tabular}




\begin{tabular}{|c|c|c|}
\hline & cumplimiento. & \\
\hline 8 Chihuahua & $\begin{array}{l}\text { La interpretación se hará } \\
\text { conforme a los criterios } \\
\text { gramatical, sistemático y } \\
\text { funcional.Artículo 3.- } \\
\text { Numeral 2. La aplicación de } \\
\text { las normas y procedimientos } \\
\text { contenidos en esta Ley } \\
\text { corresponde al Instituto } \\
\text { Estatal Electoral, al Tribunal } \\
\text { Estatal Electoral por } \\
\text { conducto de sus órganos, y } \\
\text { al Congreso del Estado en } \\
\text { sus respectivos ámbitos de } \\
\text { competencia, y su } \\
\text { interpretación se hará } \\
\text { conforme a los criterios } \\
\text { gramatical, sistemático y } \\
\text { funcional, atendiendo a lo } \\
\text { dispuesto en el cuarto párrafo } \\
\text { del artículo } 14 \text { de la } \\
\text { Constitución Política de los } \\
\text { Estados Unidos Mexicanos. }\end{array}$ & $\begin{array}{l}\text { Artículo 78.- Numeral 2. En el } \\
\text { ejercicio de la función electoral, } \\
\text { la certeza, imparcialidad, } \\
\text { independencia, legalidad y } \\
\text { objetividad, serán principios } \\
\text { rectores. }\end{array}$ \\
\hline 9 Durango & $\begin{array}{l}\text { ARTíCULO 2.- Numeral } 6 . \\
\text { La interpretación de las } \\
\text { disposiciones de esta ley, se } \\
\text { hará conforme a los criterios } \\
\text { gramatical, sistemático y } \\
\text { funcional; y en último caso, } \\
\text { se sujetará a los principios } \\
\text { generales del derecho. }\end{array}$ & $\begin{array}{l}\text { ARTÍCULO 106.- Numeral } 2 . \\
\text { Todas las actividades del } \\
\text { Instituto se regirán por los } \\
\text { principios de certeza, } \\
\text { legalidad, imparcialidad, } \\
\text { objetividad, equidad e } \\
\text { independencia. }\end{array}$ \\
\hline 10 Guanajuato & $\begin{array}{l}\text { ARTÍCULO 327. Párrafo } \\
\text { Segundo; Para resolver los } \\
\text { recursos que se interpongan } \\
\text { y a falta de disposición } \\
\text { expresa podrá hacerse uso } \\
\text { de los métodos de } \\
\text { interpretación jurídica, o en } \\
\text { su caso se aplicarán los } \\
\text { principios generales del } \\
\text { derecho; buscando siempre } \\
\text { salvaguardar la voluntad } \\
\text { manifestada en el proceso } \\
\text { electoral. (Párrafo } \\
\text { Adicionado. P.O. } 2 \text { de agosto } \\
\text { del 2002) }\end{array}$ & $\begin{array}{l}\text { ARTÍCULO 45. El Estado, los } \\
\text { partidos políticos y los } \\
\text { ciudadanos, son } \\
\text { corresponsables de la } \\
\text { preparación, desarrollo y } \\
\text { vigilancia de los procesos } \\
\text { electorales, mismos que se } \\
\text { regirán por los principios de } \\
\text { independencia, } \\
\text { profesionalismo, legalidad, } \\
\text { equidad, definitividad, } \\
\text { imparcialidad, objetividad y } \\
\text { certeza. }\end{array}$ \\
\hline
\end{tabular}




\begin{tabular}{|c|c|c|}
\hline 11 Guerrero & $\begin{array}{l}\text { ARTíCULO 4.- Párrafo } \\
\text { Segundo; La interpretación } \\
\text { de las disposiciones de esta } \\
\text { Ley, se hará conforme a los } \\
\text { criterios gramatical, } \\
\text { sistemático y funcional, } \\
\text { atendiendo a lo dispuesto en } \\
\text { el último párrafo del Artículo } \\
14 \text { de la Constitución Federal }\end{array}$ & $\begin{array}{l}\text { Artículo 4.- Párrafo Tercero; } \\
\text { En la aplicación de las normas } \\
\text { electorales, se tomarán en } \\
\text { cuenta de conformidad con el } \\
\text { artículo } 2^{\circ} \text { de la Constitución } \\
\text { Federal, los usos, costumbres } \\
\text { y formas específicas de } \\
\text { organización social y política } \\
\text { de los pueblos indígenas del } \\
\text { Estado, siempre y cuando no se } \\
\text { violen con ello los principios de } \\
\text { certeza, legalidad, } \\
\text { independencia, imparcialidad } \\
\text { y objetividad, rectores en el } \\
\text { ejercicio de la función estatal de } \\
\text { organizar las elecciones }\end{array}$ \\
\hline 12 Hidalgo & $\begin{array}{l}\text { Artículo 3.- Párrafo } \\
\text { Segundo; La interpretación } \\
\text { de esta Ley será conforme a } \\
\text { los criterios gramatical, } \\
\text { sistemático y funcional. A } \\
\text { falta de disposición expresa } \\
\text { se aplicarán los principios } \\
\text { generales del derecho. }\end{array}$ & $\begin{array}{l}\text { Artículo 68.- El desempeño de } \\
\text { esta función se regirá por los } \\
\text { principios de: legalidad, } \\
\text { certeza, imparcialidad, } \\
\text { independencia, objetividad y } \\
\text { equidad. }\end{array}$ \\
\hline 13 Jalisco & $\begin{array}{l}\text { Artículo } 4^{\circ} \text {. Numeral } 2 \text {. La } \\
\text { interpretación se hará } \\
\text { conforme a los criterios } \\
\text { gramatical, sistemático y } \\
\text { funcional, atendiendo a lo } \\
\text { dispuesto en el último párrafo } \\
\text { del artículo } 14 \text { de la } \\
\text { Constitución. }\end{array}$ & $\begin{array}{l}\text { Artículo 115. Numeral } 2 . \\
\text { Todas las actividades del } \\
\text { Instituto se regirán por los } \\
\text { principios de certeza, } \\
\text { legalidad, independencia, } \\
\text { imparcialidad, objetividad y } \\
\text { equidad. }\end{array}$ \\
\hline 14 México & $\begin{array}{l}\text { Artículo 2.- La interpretación } \\
\text { de este Código se hará } \\
\text { conforme a los criterios } \\
\text { gramatical, sistemático y } \\
\text { funcional, atendiendo a lo } \\
\text { dispuesto en el último párrafo } \\
\text { del artículo } 14 \text { de la } \\
\text { Constitución Federal. }\end{array}$ & $\begin{array}{l}\text { Artículo 82.- Las actividades } \\
\text { del Instituto se regirán por los } \\
\text { principios de certeza, } \\
\text { legalidad, independencia, } \\
\text { imparcialidad, objetividad y } \\
\text { profesionalismo. }\end{array}$ \\
\hline
\end{tabular}




\begin{tabular}{|c|c|c|}
\hline 15 Michoacán & & $\begin{array}{l}\text { Artículo 101.- El Instituto } \\
\text { Electoral de Michoacán es el } \\
\text { organismo público depositario } \\
\text { de la autoridad electoral, } \\
\text { responsable del ejercicio de la } \\
\text { función estatal de organizar las } \\
\text { elecciones y los procesos } \\
\text { plebiscitarios y de referéndum } \\
\text { en los términos de las leyes de } \\
\text { la materia. } \\
\text { En el desempeño de esta } \\
\text { función se regirá por los } \\
\text { principios de certeza, } \\
\text { legalidad, independencia, } \\
\text { imparcialidad, objetividad, } \\
\text { equidad y profesionalismo. } \\
\text { (ADICIONADO, P.O. } 8 \text { DE } \\
\text { FEBRERO DE 2001) } \\
\text { Para el desempeño de sus } \\
\text { actividades el Instituto contará } \\
\text { con un cuerpo de funcionarios } \\
\text { que sujetarán su actuación a los } \\
\text { principios de objetividad, } \\
\text { imparcialidad y } \\
\text { profesionalismo. }\end{array}$ \\
\hline 16 Morelos & $\begin{array}{l}\text { ARTICULO 1.- Párrafo } \\
\text { Tercero. La interpretación de } \\
\text { este código será conforme a } \\
\text { los criterios gramatical, } \\
\text { sistemático y funcional, } \\
\text { atendiendo a lo dispuesto en } \\
\text { el último párrafo del artículo } \\
14 \text { de la Constitución Política } \\
\text { de los Estados Unidos } \\
\text { Mexicanos }\end{array}$ & $\begin{array}{l}\text { ARTICULO 91.- Párrafo } \\
\text { Segundo. Se regirá por las } \\
\text { disposiciones que establece la } \\
\text { Constitución Política de los } \\
\text { Estados Unidos Mexicanos, la } \\
\text { Constitución Política del Estado } \\
\text { de Morelos y las de este código, } \\
\text { bajo los principios electorales } \\
\text { de: Constitucionalidad, } \\
\text { certeza, legalidad, } \\
\text { independencia, imparcialidad, } \\
\text { equidad, profesionalismo, } \\
\text { objetividad, definitividad y } \\
\text { equidad de género. }\end{array}$ \\
\hline 17 Nayarit & $\begin{array}{l}\text { Artículo 3.- La interpretación } \\
\text { y aplicación de esta ley, } \\
\text { deberá hacerse conforme a } \\
\text { la letra o a su interpretación } \\
\text { jurídica, y a falta de esta se } \\
\text { fundará en los principios } \\
\text { generales del derecho. En } \\
\text { ausencia de reglas } \\
\text { específicas y tratándose de } \\
\text { los pueblos indígenas, se } \\
\text { respetarán sus usos y } \\
\text { costumbres. }\end{array}$ & $\begin{array}{l}\text { Artículo 10.- La solicitud de } \\
\text { acreditación que se presente } \\
\text { deberá señalar los datos de } \\
\text { identificación personal y la } \\
\text { manifestación expresa de que } \\
\text { se conducirán conforme a los } \\
\text { principios de imparcialidad, } \\
\text { objetividad, certeza y legalidad, } \\
\text { y sin vínculo alguno a } \\
\text { organizaciones, partidos } \\
\text { políticos o agrupaciones no } \\
\text { reconocidas por la ley. }\end{array}$ \\
\hline
\end{tabular}




\begin{tabular}{|c|c|c|}
\hline & & $\begin{array}{l}\text { Artículo } 81 .-\ldots \text { Todas las } \\
\text { actividades del Instituto se } \\
\text { regirán por los principios de } \\
\text { certeza, legalidad, } \\
\text { independencia, imparcialidad, } \\
\text { transparencia y objetividad. }\end{array}$ \\
\hline 18 Nuevo León & $\begin{array}{l}\text { Artículo 267. Para la } \\
\text { valoración de las pruebas la } \\
\text { Comisión Estatal Electoral y } \\
\text { el Tribunal Electoral del } \\
\text { Estado, en la resolución o } \\
\text { sentencias, respectivamente, } \\
\text { se sujetarán a los principios } \\
\text { gramatical, analógico, lógico, } \\
\text { sistemático, causal o } \\
\text { teleológico tomando en } \\
\text { cuenta las disposiciones } \\
\text { especiales señaladas en este } \\
\text { capítulo. }\end{array}$ & $\begin{array}{l}\text { Artículo 3. El Estado a través de } \\
\text { los organismos electorales y } \\
\text { demás autoridades } \\
\text { competentes, los partidos } \\
\text { políticos y los ciudadanos, son } \\
\text { corresponsables de la } \\
\text { preparación, desarrollo y } \\
\text { vigilancia de los procesos } \\
\text { electorales, en los términos de } \\
\text { esta Ley. (REFORMADO, P.O. } \\
31 \text { DE JULIO DE 2008) La } \\
\text { equidad, independencia, } \\
\text { imparcialidad, legalidad, } \\
\text { objetividad y certeza, } \\
\text { definitividad y transparencia son } \\
\text { los principios rectores de la } \\
\text { función electoral. Las } \\
\text { autoridades del Estado, están } \\
\text { obligadas a garantizar la } \\
\text { efectividad del sufragio. }\end{array}$ \\
\hline 19 Oaxaca & $\begin{array}{l}\text { Artículo 4. 1. La aplicación de } \\
\text { las normas de éste código } \\
\text { corresponde al Instituto } \\
\text { Estatal Electoral, al Tribunal } \\
\text { Estatal Electoral y al } \\
\text { Congreso del Estado, en sus } \\
\text { respectivos ámbitos de } \\
\text { competencia. 2. la } \\
\text { interpretación de éste Código } \\
\text { se hará conforme a los } \\
\text { criterios gramatical, } \\
\text { sistemático y funcional, } \\
\text { atendiendo a lo dispuesto en } \\
\text { el último párrafo del artículo } \\
14 \text { de la Constitución } \\
\text { Federal. }\end{array}$ & \\
\hline 20 Puebla & $\begin{array}{l}\text { No hay una mención } \\
\text { específica a los principios } \\
\text { generales del Derecho, sino }\end{array}$ & $\begin{array}{l}\text { Artículo 3.- La aplicación de } \\
\text { este Código corresponde al } \\
\text { Congreso del Estado, al }\end{array}$ \\
\hline
\end{tabular}




\begin{tabular}{|c|c|c|}
\hline & $\begin{array}{l}\text { que directamente el Código } \\
\text { Electoral entra a mencionar } \\
\text { los principios en materia } \\
\text { electoral; mismos que se van } \\
\text { repitiendo en diversos } \\
\text { numerales. Incluso el artículo } \\
8 \text { define puntualmente cada } \\
\text { principio. }\end{array}$ & $\begin{array}{l}\text { Tribunal y a los órganos } \\
\text { electorales, en sus respectivos } \\
\text { ámbitos de su competencia. En } \\
\text { la aplicación de las normas } \\
\text { electorales se tomarán en } \\
\text { cuenta, de conformidad con lo } \\
\text { dispuesto por el artículo } 4 \text { de la } \\
\text { Constitución Federal, los usos, } \\
\text { costumbres y formas } \\
\text { específicas de organización } \\
\text { social de los pueblos indígenas } \\
\text { del Estado, siempre y cuando } \\
\text { no se transgredan con ello los } \\
\text { principios de legalidad, } \\
\text { imparcialidad, objetividad, } \\
\text { certeza e independencia, } \\
\text { rectores en el ejercicio de la } \\
\text { función estatal de organizar las } \\
\text { elecciones. }\end{array}$ \\
\hline 21 Querétaro & $\begin{array}{l}\text { ARTICULO 3. La } \\
\text { interpretación de la presente } \\
\text { Ley, para su aplicación, se } \\
\text { hará atendiendo a los } \\
\text { criterios gramatical, } \\
\text { sistemático, funcional, por } \\
\text { analogía y por mayoría de } \\
\text { razón. A falta de disposición } \\
\text { expresa se aplicarán los } \\
\text { principios generales de } \\
\text { derecho. Todo acto emitido } \\
\text { por las autoridades } \\
\text { electorales del Estado, } \\
\text { deberá estar debidamente } \\
\text { fundado y motivado. }\end{array}$ & $\begin{array}{l}\text { ARTICULO 4. Son principios } \\
\text { rectores en el ejercicio de la } \\
\text { función electoral: la certeza, } \\
\text { legalidad, independencia, } \\
\text { imparcialidad, equidad y } \\
\text { objetividad. }\end{array}$ \\
\hline $\begin{array}{l}22 \text { Quintana } \\
\text { Roo }\end{array}$ & $\begin{array}{l}\text { Artículo 1.- Las disposiciones } \\
\text { de esta Ley son de orden } \\
\text { público y de observancia } \\
\text { general en todo el Estado de } \\
\text { Quintana Roo y } \\
\text { reglamentarias de la } \\
\text { Constitución Particular. Las } \\
\text { autoridades estatales, de los } \\
\text { municipios, los organismos } \\
\text { electorales, agrupaciones } \\
\text { políticas y los partidos } \\
\text { políticos velarán por su }\end{array}$ & $\begin{array}{l}\text { Artículo 1.- Las disposiciones de } \\
\text { esta Ley son de orden público y } \\
\text { de observancia general en todo } \\
\text { el Estado de Quintana Roo y } \\
\text { reglamentarias de la } \\
\text { Constitución Particular. Las } \\
\text { autoridades estatales, de los } \\
\text { municipios, los organismos } \\
\text { electorales, agrupaciones } \\
\text { políticas y los partidos políticos } \\
\text { velarán por su estricta } \\
\text { aplicación y cumplimiento. Las }\end{array}$ \\
\hline
\end{tabular}




\begin{tabular}{|c|c|c|}
\hline & $\begin{array}{l}\text { estricta aplicación y } \\
\text { cumplimiento. Las } \\
\text { autoridades electorales, en el } \\
\text { ejercicio de sus funciones, } \\
\text { ajustarán sus actos a los } \\
\text { principios constitucionales } \\
\text { rectores en materia electoral } \\
\text { de legalidad, certeza, } \\
\text { independencia, imparcialidad } \\
\text { y objetividad. }\end{array}$ & $\begin{array}{l}\text { autoridades electorales, en el } \\
\text { ejercicio de sus funciones, } \\
\text { ajustarán sus actos a los } \\
\text { principios constitucionales } \\
\text { rectores en materia electoral de } \\
\text { legalidad, certeza, } \\
\text { independencia, imparcialidad y } \\
\text { objetividad. }\end{array}$ \\
\hline $\begin{array}{l}23 \text { San Luis } \\
\text { Potosí }\end{array}$ & $\begin{array}{l}\text { ARTÍCULO } 8^{\circ} \text {. Todos los } \\
\text { procesos electorales que se } \\
\text { desarrollen en el Estado } \\
\text { quedarán sujetos a lo } \\
\text { establecido en la presente } \\
\text { Ley. En lo no previsto y en } \\
\text { cuanto no contravengan lo } \\
\text { establecido por la } \\
\text { Constitución Política del } \\
\text { Estado y este ordenamiento, } \\
\text { se aplicarán supletoriamente } \\
\text { las disposiciones de orden } \\
\text { federal relativas a la materia. }\end{array}$ & $\begin{array}{l}\text { ARTÍCULO 55. EI Consejo } \\
\text { Estatal Electoral es un } \\
\text { organismo de carácter } \\
\text { permanente, autónomo e } \\
\text { independiente en sus } \\
\text { decisiones y funcionamiento, } \\
\text { con personalidad jurídica y } \\
\text { patrimonio propios, encargado } \\
\text { de vigilar el cumplimiento de las } \\
\text { disposiciones constitucionales, } \\
\text { legales y reglamentarias de la } \\
\text { materia electoral, así como de } \\
\text { preparar, desarrollar, calificar y } \\
\text { vigilar los procesos electorales } \\
\text { estatales y municipales. El } \\
\text { Consejo Estatal Electoral velará } \\
\text { por que los principios de } \\
\text { certeza, legalidad, } \\
\text { imparcialidad, independencia, } \\
\text { objetividad y equidad guíen } \\
\text { todas las actividades de los } \\
\text { organismos electorales del } \\
\text { Estado. El patrimonio del } \\
\text { Consejo se integra con los } \\
\text { bienes muebles e inmuebles } \\
\text { que se adquieran y/o destinen } \\
\text { al cumplimiento de su objeto, } \\
\text { así como con las partidas que } \\
\text { anualmente se le señalen en el } \\
\text { presupuesto de egresos del } \\
\text { Estado. }\end{array}$ \\
\hline 24 Sinaloa & $\begin{array}{l}\text { ARTÍCULO 2.- La aplicación } \\
\text { de esta ley, corresponde a } \\
\text { los Consejos Electorales, a } \\
\text { las Mesas Directivas de } \\
\text { Casilla, al Tribunal Estatal }\end{array}$ & $\begin{array}{l}\text { Artículo } 47 .- \text {.... Las autoridades } \\
\text { electorales son responsables de } \\
\text { aplicar y vigilar el cumplimiento } \\
\text { de esta Ley y de las } \\
\text { disposiciones constitucionales }\end{array}$ \\
\hline
\end{tabular}




\begin{tabular}{|c|c|c|}
\hline & $\begin{array}{l}\text { Electoral y al Congreso del } \\
\text { Estado, en sus respectivos } \\
\text { ámbitos de competencia. } \\
\text { (REFORMADO, P.O. } 05 \text { DE } \\
\text { ABRIL DE 1995) La } \\
\text { interpretación de la ley se } \\
\text { hará conforme a los criterios } \\
\text { gramatical, sistemático y } \\
\text { funcional, atendiendo a lo } \\
\text { dispuesto por el último } \\
\text { párrafo del artículo } 14 \text { de la } \\
\text { Constitución Política de los } \\
\text { Estados Unidos Mexicanos. }\end{array}$ & $\begin{array}{l}\text { en materia electoral. Regirán su } \\
\text { actuación por los principios de } \\
\text { certeza, legalidad, } \\
\text { independencia, imparcialidad y } \\
\text { objetividad. }\end{array}$ \\
\hline 25 Sonora & $\begin{array}{l}\text { ARTICULO 40.- Los } \\
\text { ciudadanos, a través de los } \\
\text { organismos electorales, y las } \\
\text { autoridades competentes } \\
\text { tendrán a su cargo, en el } \\
\text { ámbito de sus respectivas } \\
\text { competencias, cuidar y } \\
\text { garantizar el desarrollo del } \\
\text { proceso, vigilar que las } \\
\text { actividades de los partidos se } \\
\text { realicen con apego a la ley, y } \\
\text { velar por la efectividad del } \\
\text { sufragio y la autenticidad e } \\
\text { imparcialidad de las } \\
\text { elecciones, en los términos } \\
\text { establecidos por la } \\
\text { Constitución Federal, la } \\
\text { Constitución Local, la Ley } \\
\text { Orgánica de Administración } \\
\text { Municipal y el presente } \\
\text { ordenamiento. }\end{array}$ & $\begin{array}{l}\text { ARTICULO 8o.- Es derecho } \\
\text { exclusivo de los ciudadanos } \\
\text { mexicanos, participar como } \\
\text { observadores de las actividades } \\
\text { electorales en el Estado, } \\
\text { durante las campañas } \\
\text { electorales y/o la jornada } \\
\text { electoral, en la forma y términos } \\
\text { que determine el Consejo } \\
\text { Estatal para cada proceso, de } \\
\text { acuerdo con las siguientes } \\
\text { bases: I.- Los ciudadanos que } \\
\text { pretendan actuar como } \\
\text { observadores deberán señalar } \\
\text { en el escrito de solicitud de } \\
\text { registro, los datos de } \\
\text { identificación personal, } \\
\text { anexando fotocopia de su } \\
\text { credencial con fotografía para } \\
\text { votar, los motivos de su } \\
\text { participación y la manifestación } \\
\text { expresa de que si obtienen el } \\
\text { registro, se conducirán } \\
\text { conforme a los principios de } \\
\text { imparcialidad, objetividad, } \\
\text { certeza y legalidad y sin ligas a } \\
\text { partido u organización política } \\
\text { alguna; }\end{array}$ \\
\hline 26 Tabasco & $\begin{array}{l}\text { ARTÍCULO 3. La aplicación } \\
\text { de las normas de esta Ley, } \\
\text { corresponde al Instituto } \\
\text { Estatal, al Tribunal Electoral, } \\
\text { y a la Cámara de Diputados }\end{array}$ & $\begin{array}{l}\text { ARTÍCULO 124. En su conjunto } \\
\text { todas las funciones y } \\
\text { actividades del Instituto Estatal } \\
\text { se regirán por los principios } \\
\text { básicos de certeza, legalidad, }\end{array}$ \\
\hline
\end{tabular}




\begin{tabular}{|c|c|c|}
\hline & $\begin{array}{l}\text { en sus respectivos ámbitos } \\
\text { de competencia. La } \\
\text { interpretación se hará } \\
\text { conforme a los criterios } \\
\text { gramatical, sistemático y } \\
\text { funcional, atendiendo a lo } \\
\text { dispuesto en el artículo } 14 \\
\text { último párrafo de la } \\
\text { Constitución Federal, o en su } \\
\text { caso, se fundará en los } \\
\text { principios generales del } \\
\text { derecho. }\end{array}$ & $\begin{array}{l}\text { independencia, imparcialidad y } \\
\text { objetividad. Para el desempeño } \\
\text { de sus actividades el Instituto } \\
\text { Estatal contará con el personal } \\
\text { calificado necesario para } \\
\text { prestar el servicio profesional } \\
\text { electoral y en una rama } \\
\text { administrativa que se regirá por } \\
\text { el estatuto que al efecto } \\
\text { apruebe el Consejo Estatal, en } \\
\text { el que se establecerán los } \\
\text { respectivos mecanismos de } \\
\text { ingreso, formación, promoción y } \\
\text { desarrollo. }\end{array}$ \\
\hline 27 Tamaulipas & $\begin{array}{l}\text { Artículo 4.- La interpretación } \\
\text { de este Código se hará } \\
\text { conforme a los criterios } \\
\text { gramatical, sistemático y } \\
\text { funcional, atendiendo a lo } \\
\text { dispuesto en el último párrafo } \\
\text { del artículo } 14 \text { de la } \\
\text { Constitución Política de los } \\
\text { Estados Unidos Mexicanos. } \\
\text { Además en materia electoral } \\
\text { se observará el princiío de } \\
\text { publicidad procesal. }\end{array}$ & $\begin{array}{l}\text { Artículo } 120 .- \text { Todas las } \\
\text { actividades del Instituto se } \\
\text { regirán por los principios de } \\
\text { certeza, imparcialidad, } \\
\text { independencia, legalidad y } \\
\text { objetividad. }\end{array}$ \\
\hline 28 Tlaxcala & $\begin{array}{l}\text { Artículo 3. La interpretación } \\
\text { de este Código se hará } \\
\text { conforme a los criterios } \\
\text { gramatical, sistemático y } \\
\text { funcional o en su caso, se } \\
\text { aplicarán los principios } \\
\text { generales del derecho. }\end{array}$ & $\begin{array}{l}\text { Artículo 2. Son principios } \\
\text { rectores de la función estatal } \\
\text { electoral los de } \\
\text { constitucionalidad, legalidad, } \\
\text { certeza, autonomía, } \\
\text { independencia, imparcialidad, } \\
\text { equidad, objetividad y } \\
\text { profesionalismo. }\end{array}$ \\
\hline 29 Veracruz & $\begin{array}{l}\text { Artículo 2. La aplicación de } \\
\text { las normas de este Código } \\
\text { corresponde al Instituto } \\
\text { Electoral Veracruzano, a la } \\
\text { Sala Electoral del Tribunal } \\
\text { Superior de Justicia y al } \\
\text { Congreso del Estado, en sus } \\
\text { respectivos ámbitos de } \\
\text { competencia. La } \\
\text { interpretación de las } \\
\text { disposiciones de este } \\
\text { Código, se hará conforme a } \\
\text { los criterios gramatical, } \\
\text { sistemático y funcional, } \\
\text { atendiendo a lo dispuesto en } \\
\text { el último párrafo del artículo }\end{array}$ & $\begin{array}{l}\text { Artículo 81.- .En el desempeño } \\
\text { de la función electoral, el } \\
\text { Instituto se regirá por los } \\
\text { principios de legalidad, } \\
\text { imparcialidad, objetividad, } \\
\text { certeza, independencia, } \\
\text { profesionalismo, equidad y } \\
\text { definitividad. }\end{array}$ \\
\hline
\end{tabular}




\begin{tabular}{|c|c|c|}
\hline & $\begin{array}{l}14 \text { de la Constitución Política } \\
\text { de los Estados Unidos } \\
\text { Mexicanos. Para el } \\
\text { desempeño de sus } \\
\text { funciones, los organismos } \\
\text { electorales establecidos por } \\
\text { la Constitución del Estado y } \\
\text { este Código contarán con el } \\
\text { apoyo y colaboración de las } \\
\text { autoridades estatales y } \\
\text { municipales. }\end{array}$ & \\
\hline 30 Yucatán & $\begin{array}{l}\text { Artículo 3.- La aplicación de } \\
\text { las normas de este Código } \\
\text { corresponde, en sus } \\
\text { respectivos ámbitos de } \\
\text { competencia, al Instituto } \\
\text { Electoral del Estado y al } \\
\text { Tribunal Electoral del Estado. } \\
\text { (REFORMADO, D.O. } 30 \text { DE } \\
\text { JUNIO DE 2003) La } \\
\text { interpretación de este Código } \\
\text { se hará conforme a los } \\
\text { criterios gramatical, } \\
\text { sistemático y funcional. A } \\
\text { falta de disposición expresa, } \\
\text { se aplicarán los principios } \\
\text { generales del derecho con } \\
\text { base en lo dispuesto en el } \\
\text { último párrafo del artículo } 14 \\
\text { de la Constitución General de } \\
\text { la República. }\end{array}$ & $\begin{array}{l}\text { Artículo 1.- Las disposiciones de } \\
\text { este Código son de orden } \\
\text { público y de observancia } \\
\text { general en el Estado de } \\
\text { Yucatán. Reglamentan las } \\
\text { normas constitucionales que se } \\
\text { refieren a la función estatal para } \\
\text { organizar las elecciones de los } \\
\text { integrantes de los Poderes } \\
\text { Legislativo, Ejecutivo y de los } \\
\text { ayuntamientos; los derechos y } \\
\text { obligaciones político-electorales } \\
\text { de los ciudadanos; los } \\
\text { derechos, obligaciones y } \\
\text { prerrogativas de los partidos } \\
\text { políticos y el sistema de medios } \\
\text { de impugnación para garantizar } \\
\text { los actos y resoluciones } \\
\text { electorales, mediante los } \\
\text { principios rectores de certeza, } \\
\text { legalidad, independencia, } \\
\text { imparcialidad y objetividad. }\end{array}$ \\
\hline 31 Zacatecas & $\begin{array}{l}\text { Artículo 2.- Criterios para la } \\
\text { interpretación de la Ley. 1. La } \\
\text { interpretación de esta Ley se } \\
\text { hará conforme a los criterios } \\
\text { gramatical, sistemático, } \\
\text { funcional y a la jurisprudencia } \\
\text { o en los principios generales } \\
\text { del Derecho. }\end{array}$ & $\begin{array}{l}\text { Artículo 3.- Aplicación de la Ley. } \\
\text { Autoridades Competentes. 1. La } \\
\text { aplicación de las disposiciones } \\
\text { de esta ley corresponde en el } \\
\text { ámbito de sus respectivas } \\
\text { competencias, al Instituto, al } \\
\text { Tribunal de Justicia Electoral del } \\
\text { Estado y a la Legislatura del } \\
\text { Estado. Párrafo reformado } \\
\text { POG 03-10-2009. 2. Es } \\
\text { responsabilidad de las } \\
\text { respectivas autoridades, así } \\
\text { como de los consejos } \\
\text { electorales y de las mesas } \\
\text { directivas de casilla, que en los } \\
\text { procesos electorales locales se }\end{array}$ \\
\hline
\end{tabular}




\begin{tabular}{|c|c|c|}
\hline & & $\begin{array}{l}\text { cumpla con los principios } \\
\text { rectores de libertad, } \\
\text { efectividad del sufragio, } \\
\text { certeza, legalidad, equidad, } \\
\text { independencia, imparcialidad } \\
\text { y objetividad establecidos en la } \\
\text { Constitución y esta ley. Párrafo } \\
\text { reformado POG 03-10-2009. } \\
\text { 3. La promoción de la } \\
\text { participación ciudadana para el } \\
\text { ejercicio del derecho al sufragio } \\
\text { corresponde al Instituto } \\
\text { Electoral del Estado de } \\
\text { Zacatecas, a los partidos } \\
\text { políticos y sus candidatos. El } \\
\text { Instituto emitirá las reglas a las } \\
\text { que se sujetarán las campañas } \\
\text { de promoción del voto que } \\
\text { realicen otras organizaciones. } \\
\text { Párrafo adicionado POG 03-10- } \\
2009\end{array}$ \\
\hline $\begin{array}{l}32 \text { Distrito } \\
\text { Federal }\end{array}$ & $\begin{array}{l}\text { Artículo 2. La aplicación de } \\
\text { las normas de este Código } \\
\text { corresponde a la Asamblea } \\
\text { Legislativa del Distrito } \\
\text { Federal, al Instituto Electoral } \\
\text { del Distrito Federal y al } \\
\text { Tribunal Electoral del Distrito } \\
\text { Federal, en sus respectivos } \\
\text { ámbitos de competencia, } \\
\text { quienes tendrán la obligación } \\
\text { de preservar su estricta } \\
\text { observancia y cumplimiento. } \\
\text { La interpretación y } \\
\text { aplicación del presente } \\
\text { Código se hará conforme a } \\
\text { la letra, o interpretación } \\
\text { jurídica de la misma, y a } \\
\text { falta de ésta, se fundará en } \\
\text { los principios generales del } \\
\text { derecho, de acuerdo con lo } \\
\text { dispuesto en el último } \\
\text { párrafo del artículo } 14 \text { de la } \\
\text { Constitución Política de los } \\
\text { Estados Unidos Mexicanos. } \\
\text { Las autoridades electorales, } \\
\text { para el debido cumplimiento } \\
\text { de sus funciones, se regirán } \\
\text { por los principios de certeza, }\end{array}$ & $\begin{array}{l}\text { Artículo 2. La aplicación de las } \\
\text { normas de este Código } \\
\text { corresponde a la Asamblea } \\
\text { Legislativa del Distrito Federal, } \\
\text { al Instituto Electoral del Distrito } \\
\text { Federal y al Tribunal Electoral } \\
\text { del Distrito Federal, en sus } \\
\text { respectivos ámbitos de } \\
\text { competencia, quienes tendrán } \\
\text { la obligación de preservar su } \\
\text { estricta observancia y } \\
\text { cumplimiento. La interpretación } \\
\text { y aplicación del presente } \\
\text { Código se hará conforme a la } \\
\text { letra, o interpretación jurídica de } \\
\text { la misma, y a falta de ésta, se } \\
\text { fundará en los principios } \\
\text { generales del derecho, de } \\
\text { acuerdo con lo dispuesto en el } \\
\text { último párrafo del artículo } 14 \text { de } \\
\text { la Constitución Política de los } \\
\text { Estados Unidos Mexicanos. Las } \\
\text { autoridades electorales, para el } \\
\text { debido cumplimiento de sus } \\
\text { funciones, se regirán por los } \\
\text { principios de certeza, } \\
\text { legalidad, independencia, } \\
\text { imparcialidad, objetividad y }\end{array}$ \\
\hline
\end{tabular}




\begin{tabular}{|l|l|l|}
\hline & legalidad, independencia, & equidad. Además, en materia \\
imparcialidad, objetividad y & electoral se observará el \\
& equidad. Además, en materia & principio de publicidad procesal. \\
electoral se observará el & Las autoridades electorales \\
principio de publicidad & solamente podrán intervenir en \\
procesal. Las autoridades & los asuntos internos de los \\
& electorales solamente podrán & Partidos en los términos que \\
intervenir en los asuntos & expresamente señale la \\
internos de los Partidos en & legislación aplicable. \\
& los términos que & \\
expresamente señale la & \\
legislación aplicable. & \\
\hline
\end{tabular}

\section{Conclusiones}

Podemos resaltar que en todas las legislaciones electorales de las entidades federativas que conforman al Estado Mexicano son establecidos principios generales de derecho y principios rectores de la función electoral, sujetándose en un primer instante a lo dispuesto por la Constitución Política de los Estados Unidos Mexicanos $y$, en un segundo instante, en el enriquecimiento mismo de estos principios, agregando nuevos principios tomando como referencia las condiciones propias de cada entidad.

Una de las conclusiones de esta exposición es que el derecho como ciencia se especializa cada vez más, dando pie al estudio de diversos campos conceptuales y prácticos.

No sólo el establecimiento normativo de principios ético normativos en el marco legal sino el ejercicio o efectivización plena de éstos fortalecerán la consolidación de un Estado Constitucional de Derecho con una forma de gobierno democrática.

Así, la labor del ciudadano y del estudioso del derecho resulta trascendental ya que es responsabilidad del primero procurar conocer, en la medida de lo posible, los fenómenos que acontecen en su entorno inmediato para así, tener conciencia plena del ejercicio de sus derechos y la responsabilidad que esta acción conlleva; en relación a los profesionales del derecho, su responsabilidad radica en interpretar esos fenómenos sociales, políticos, económicos y culturales para, así, materializarlos en preceptos normativos y velar por su pleno ejercicio.

La democracia, por ende, no sólo debe de entenderse desde su aspecto formal y estrictamente político sino, de igual forma, desde su aspecto sustancial y de contenido.

Nos queda claro, que es condición necesaria para la democracia que existan una serie de reglas y normas fundamentales para consolidar la integración del poder político y la posibilidad de participación de los ciudadanos en la toma de decisiones públicas a través de estos mecanismos institucionalizados de manera 
formal pero punto relevante es lo relativo al contenido de las decisiones de la autoridad formal emanada de la voluntad popular.

Sin el estudio de estos dos aspectos de esta forma de gobierno la democracia en México será inacabada.

Entender la importancia del derecho electoral, desde lo formal y sustancial, no sólo conlleva el conocimiento técnico jurídico de una rama del derecho como ciencia, sino es también el entendimiento de un proceso complejo político y social que tiene como base de contenido la integración y consolidación de la voluntad popular, por ello, aportamos al debate una serie de ideas plasmadas en este estudio lo que abre la posibilidad de posteriores análisis en los que se puede profundizar al respecto.

\section{Fuentes DE CONSULTA}

- ARAGÓN, Manuel (1989) Constitución y democracia, Madrid

- ARISTÓTEles (s.f) La Política, Libro Primero, En línea en: http://www.bibliojuridica.org/libros/2/766/3.pdf

- BOBBIO, Norberto / Bovero Michelangelo; Sociedad y estado en la filosofía moderna, México: Fondo de Cultura Económica.

- BOBBIO, Norberto (1994) Estado, gobierno y sociedad, México: Fondo de Cultura Económica.

- BOBBIO, Norberto, Nicola Matteucci y Gianfranco Pasquino, (2005) Diccionario de Política, México: Ed. Siglo XXI.

- BOVERO, Michelangelo (2002) Globalización, democracia, derechos ¿siete globalizaciones?; publicado en Justicia Electoral: "Revista del Tribunal Electoral del Poder Judicial de la Federación" Número 1 7, p.51

- BURGOA O. Ignacio (1998) Diccionario de Derecho Constitucional, Garantías y Amparo, México: Ed. Porrúa.

- CABO, De Carlos (1997) Contra el consenso. Estudios sobre el Estado constitucional y el constitucionalismo del Estado social, México.

- CARBONELL, Miguel (1998) Constitución, reforma constitucional y fuentes del Derecho en México. México: UNAM.

- CARPIZO, Jorge; MADRAZO, Jorge, (1991) Derecho Constitucional, México: UNAM.

- COMANDUCCI, Paolo (2002) Formas de (Neo) Constitucionalismo: Un análisis Metateórico; en ISONOMÍA.

- DAHL, Robert (1971) Polyarchy: Participation and Opposition, New Haven: Yale University Press. 
- DEL CASTILLO, Alberto (2000) Diccionario de Derecho Electoral; Instituto Estatal Electoral de Hidalgo.

- (1998) Diccionario Jurídico Mexicano, Instituto de Investigaciones Jurídicas, Universidad Nacional Autónoma de México, México: Ed. Porrúa

- FERRAJOLI, Luigi (2003) Sobre la definición de democracia. Una discusión con Michelangelo Bovero, en ISONOMIA.

- FIX-ZAMUDIO, Héctor (s.f) Derecho Constitucional Mexicano y Comparado; Editada por el Tribunal Electoral del Poder Judicial del Estado de Jalisco y el Instituto de Investigaciones y Capacitación Electoral, En línea en: http://www.diputados.gob.mx http://www.diputados.gob.mx/LeyesBiblio/gobiernos.htm

- KELSEN, Hans (s.f) Qué es la justicia. En línea en: http://usmapanama.com/wpcontent/uploads/2010/02/09-Hans-Kelsen.-LaJuticia.pdf

- LUCAS Verdú, Pablo (1981) Curso de Derecho Político, Madrid.

- MONTERO ZENDEJAS, Daniel (1991) Derecho Político Mexicano, México: Ed. Trillas.

- MONTESQUIEU (1995) El espíritu de las Leyes. Trad. De Mercedes Blázquez y Pedro de Vega, Madrid.

- PRZEWORSKI, Adam (1998) Democracia y Representación, Publicado en la "Revista del CLAD Reforma y Democracia", Caracas.

- PRZEWORSKI, Adam (1998) El Estado y el ciudadano, Política y Gobierno.

- RAWLS, John (2002) La justicia como equidad. Ed. Paidós.

- SCHUMPETER, Joseph (1961) Capitalismo, Socialismo y Democracia, México: Editora Fondo de Cultura,

- Suprema Corte de Justicia de la Nación (2006) Serie Grandes Temas del Constitucionalismo Mexicano: El Federalismo, México, D. F.

- TENA Ramírez, Felipe (1990) Derecho Constitucional mexicano. México

- VÁZQUEZ, Rodolfo (1997) Educación liberal. Un enfoque igualitario y democrático, México. 